The University of Maine

DigitalCommons@UMaine

Marine Sciences Faculty Scholarship

School of Marine Sciences

12-31-2002

\title{
Evolution of 1996-1999 La Niña and El Niño Conditions Off the Western Coast of South America: A Remote Sensing Perspective
}

\author{
M.E. Carr \\ P. T. Strub \\ Andrew Thomas \\ University of Maine - Main, thomas@maine.edu \\ J.L. Blanco
}

Follow this and additional works at: https://digitalcommons.library.umaine.edu/sms_facpub

\section{Repository Citation}

Carr, M. E.; Strub, P. T.; Thomas, Andrew; and Blanco, J. L., "Evolution of 1996-1999 La Niña and El Niño Conditions Off the Western Coast of South America: A Remote Sensing Perspective" (2002). Marine Sciences Faculty Scholarship. 46.

https://digitalcommons.library.umaine.edu/sms_facpub/46 


\title{
Evolution of 1996-1999 La Niña and El Niño conditions off the western coast of South America: A remote sensing perspective
}

\author{
Mary-Elena Carr \\ Jet Propulsion Laboratory, California Institute of Technology, Pasadena, California, USA \\ P. Ted Strub \\ College of Oceanic and Atmospheric Sciences, Oregon State University, Corvallis, Oregon, USA \\ Andrew C. Thomas \\ School of Marine Sciences, University of Maine, Orono, Maine, USA
}

Jose Luis Blanco ${ }^{1}$

Instituto de Fomento Pesquero, Valparaíso, Chile

Received 17 October 2001; revised 8 August 2002; accepted 28 August 2002; published 31 December 2002.

[1] We present the evolution of oceanographic conditions off the western coast of South America between 1996 and 1999, including the cold periods of 1996 and 1998-1999 and the 1997-1998 El Niño, using satellite observations of sea level, winds, sea surface temperature (SST), and chlorophyll concentration. Following a period of cold SST and low sea levels in 1996, both were anomalously high between March 1997 and May 1998. The anomalies were greatest between $5^{\circ} \mathrm{S}$ and $15^{\circ} \mathrm{S}$, although they extended beyond $40^{\circ} \mathrm{S}$. Two distinct peaks in sea level and SST occurred in June-July 1997 and December 1997 to January 1998, separated by a relaxation period (August-November) of weaker anomalies. Satellite winds were upwelling favorable throughout the time period for most of the region and in fact increased between November 1997 and March 1998 between $5^{\circ} \mathrm{S}$ and $25^{\circ} \mathrm{S}$. Satellite-derived chlorophyll concentrations are available for November 1996 to June 1997 (Ocean Color and Temperature Sensor (OCTS)) and then from October 1997 to present (Sea-viewing Wide Field-of-view Sensor (SeaWiFS)). Near-surface chlorophyll concentrations fell from May to June 1997 and from December 1997 to March 1998. The decrease was more pronounced in northern Chile than off the coast of Peru or central Chile and was stronger for larger cross-shelf averaging bins since nearshore concentrations remained relatively high. INDEX TERMS: 4522 Oceanography: Physical: El Niño; 4516 Oceanography: Physical: Eastern boundary currents; 4215 Oceanography: General: Climate and interannual variability (3309); 4275 Oceanography: General: Remote sensing and electromagnetic processes (0689); 4855 Oceanography: Biological and Chemical: Plankton; KEYWORDS: Eastern boundary currents, Peru-Humboldt Current, remote sensing, El Niño-La Niña, coastal upwelling

Citation: Carr, M.-E., P. T. Strub, A. C. Thomas, and J. L. Blanco, Evolution of 1996-1999 La Niña and El Niño conditions off the western coast of South America: A remote sensing perspective, J. Geophys. Res., 107(C12), 3236, doi:10.1029/2001JC001183, 2002.

\section{Introduction}

[2] Eastern boundary current (EBC) regions are extremely productive, accounting for $5 \%$ of global oceanic primary production and $17 \%$ of global fish catch, although their area makes up less than $1 \%$ of the world ocean [Pauly and Christensen, 1995]. The high productivity is a consequence of alongshore equatorward winds which lead to upwelling of cool, nutrient-rich water. The Peru-Chile Current is the most productive among the EBC regions in terms of fish catch

\footnotetext{
${ }^{1}$ Now at Center for Coastal Physical Oceanography, Old Dominion University, Norfolk, Virginia, USA.

Copyright 2002 by the American Geophysical Union. 0148-0227/02/2001JC001183
}

[Barber and Smith, 1981; Bakun, 1996; Strub et al., 1998; Carr, 2002].

[3] During El Niño, one of the two extreme states of the ocean-atmosphere system of the Pacific Ocean [Barber, 1988; Philander, 1989], the coasts of Ecuador, Peru, and Chile experience modified circulation patterns and water properties, with increased sea levels and isotherm depths [Strub et al., 1998; Blanco et al., 2002]. Winds usually remain upwelling favorable during El Niño events, but the nutrient supply to the upper layer is generally reduced as upwelled water originates above the deepened nutricline, thus affecting phytoplankton biomass, species composition, and production. Cold or La Niña periods have received less attention but they generally lead to shallower nutriclines, which would entail increased nutrient supply, higher phyto- 
plankton biomass, and primary production. These conditions have been recorded in the equatorial Pacific and in the California Current [Murtugudde et al., 1999; Behrenfeld et al., 2001; Hayward, 1999; Bograd et al., 2000]. Off the coast of Chile, minima in larval fish abundance and landings occurred in warm El Niño years, while cold years were found to be intermediate [Morales et al., 1996; Yáñez et al., 1995].

[4] The 1997-1998 El Niño is the first major event that can be adequately studied using a full suite of remote sensing measurements. Sea surface height (SSH) and sea surface temperature (SST) were measured continuously throughout the period by the TOPEX/Poseidon altimeter (T/P) and the Advanced High Resolution Radiometer (AVHRR), respectively. These observations were used not only to monitor the evolution of oceanographic conditions but also as input for predictive models [Barnston et al., 1999]. From 1996 to present, scatterometers on the European Remote Sensing satellites (ERS-1 and ERS-2) made measurements of wind speed and direction. The ADEOS platform, launched in August 1996, carried the NASA Scatterometer (NSCAT), which measured surface winds over the ocean, and the Japanese Ocean Color and Temperature Sensor (OCTS), which measured surface chlorophyll concentration, until the premature failure of the satellite in June 1997. The launch of SeaStar with the Sea-viewing Wide Field-of-view Sensor (SeaWiFS) has provided measurements of chlorophyll from September 1997 to present.

[5] Thomas et al. [1994] found that data gaps in the 20$\mathrm{km}$ monthly mean product from the Coastal Zone Color Scanner (CZCS) off western South America made it difficult to quantify anomalies associated with the 1982-1983 El Niño or to elucidate the relationship between wind forcing and chlorophyll concentrations. Even after remapping the data at $4 \mathrm{~km}$ and daily resolution, interannual variability could not be resolved adequately by CZCS [Thomas, 1999]. The impact of the 1997-1998 El Niño event off northern Chile $\left(18^{\circ}-24^{\circ} \mathrm{S}\right)$ was addressed by Thomas et al. [2001a] using SeaWiFS and OCTS data. They found that strong chlorophyll anomalies were associated with anomalies in SST but were not related to local changes in upwelling wind forcing. The background seasonal cycle was different from that seen from CZCS [Thomas et al., 1994; Thomas, 1999]: maximum chlorophyll concentrations (in normal years) were in phase with wind forcing.

[6] To look at more global patterns, Thomas et al. [2001b] used 3 years of SeaWiFS to quantify the climatological seasonal cycle of chlorophyll over all four EBC regions. The seasonal cycle of the Chile Current was in phase with wind forcing over virtually all of the Chilean coast. Off Peru, the spring maximum in wind forcing is $180^{\circ}$ out of phase with the fall maximum in chlorophyll, consistent with ship data [Chávez, 1995]. Interannual variability in chlorophyll and primary production for 1997 to 1999 was addressed for all four EBCs by Carr [2002]. This study found that phytoplankton biomass and production in the Peru-Chile Current in 1999 and 1997 were quite similar, while 1998 was much lower.

[7] Strub and James [2002a] use T/P data to compare the seasonal cycles of SSH and transport along the west coasts of North America and South America, and the evolution of El Niño conditions in 1997-1998. The basic premise was that the two regions might present hemispheric symmetry given a common remote trigger in the equator and poleward communication via coastally trapped waves. They found that topography and local wind forcing disrupted the expected symmetry; disruption that was further reinforced by the hemispheric phase shift of the seasonal cycles in circulation and wind forcing. Thus, the boreal springsummer and winter maxima in the two peaks of equatorial SSH in 1997-1998 were modulated in opposite directions by the seasonal wind cycle in each hemisphere and for each peak, i.e., maximum upwelling (downwelling) favorable winds in the first SSH maximum in the Northern (Southern) Hemisphere and downwelling (upwelling) favorable in the second SSH maximum in the Southern (Northern) Hemisphere.

[8] To our knowledge no previous study incorporates the information acquired from all major sea-viewing satellites to document the evolution of oceanographic conditions during the 1997-1998 El Niño along the entire west coast of South America. We build upon previous work which focused on large-scale comparisons of all four EBCs, or one or two data sets (SSH or ocean color), and expand from a regional focus (northern Chile) to the entire Peru-Chile Current. We aim to identify the timing and amplitude of the onset of anomalous conditions and to quantify the biological response. A better understanding of the impact of strong El Niño conditions on the oceanographic system is crucially important to understand the consequences for higher trophic levels and to improve diagnostic and predictive modeling efforts of the region. We address here changes in SSH and geostrophic flow residuals, offshore Ekman transport, SST and chlorophyll concentration, as well as the spatial extent of the impact in regions poleward and offshore of the forcing. To place our study site and period within a greater context, we compare the 1997-1998 El Niño event to that of 1982-1983 and to studies made off the west coast of North America in 1997-1998. We also contrast the present large-scale results with more focused regional studies in the Peru-Chile Current. The data are described in section 2, results are presented in section 3, section 4 is the discussion, and conclusions are given in section 5 .

\section{Data and Methods}

[9] In an attempt to best describe the conditions associate with the El Niño event, we used all existing sea-viewing data sets and tide gauge data (Table 1). In previous work we concentrated on ocean color and SST [Thomas et al., 2001a] or on altimetry [Strub and James, 2002a]. Here we bring together the response to El Niño conditions as seen in $\mathrm{SSH}$, SST, wind patterns, upwelling of cold water, and spatial patterns of chlorophyll concentration.

[10] To provide a long term context for the 1997-1998 El Niño we compared tide gauge sea level data and a blended satellite in situ SST product. The sea level data from tide gauge stations along the west coast of South America were obtained from the University of Hawaii Sea Level Center, where they have been adjusted for the inverse barometer effect using atmospheric pressure from the U.S. Climate Analysis Center. The SST time series between 1982 and 1999 which we compared with the tide gauge sea level is an 
Table 1. Data Sets Used in the Study

\begin{tabular}{lcccc}
\hline \multicolumn{1}{c}{ Variable } & Sensor-product & Period & Resolution & Purpose \\
\hline SSH & Tide gauges & $1981-1999$ & 8 stations & Context \\
SST & AVHRR-Reynolds & $1982-1999$ & $1^{\circ}$ & Context \\
Chl concentration & CZCS & $1981-1984$ & $1^{\circ}$ & $1982-1983$ \\
SSH & T/P & $1996-1999$ & $6, \sim 250 \mathrm{~km}$ & $1997-1998$ \\
SST & AVHRR-Pathfinder & $1996-1999$ & $9 \mathrm{~km}$ & $1997-1998$ \\
Chl concentration & OCTS & $1996-1997$ & $9 \mathrm{~km}$ & $1997-1998$ \\
Chl concentration & SeaWiFS & $1997-1999$ & $9 \mathrm{~km}$ & $1997-1998$ \\
Ekman transport & ERS-1 & 1996 & $1^{\circ}$ & $1997-1998$ \\
Ekman transport & NSCAT & $1996-1997$ & $0.5^{\circ}$ & $1997-1998$ \\
Ekman transport & ERS-2 & $1997-1999$ & $1^{\circ}$ & $1997-1998$ \\
\hline
\end{tabular}

All data sets are used at monthly resolution. The resolution of the T/P SSH is $6 \mathrm{~km}$ along track and $200-300 \mathrm{~km}$ between tracks.

optimally interpolated combination of AVHRR and ship observations [Reynolds and Smith, 1994] at monthly and $1^{\circ}$ resolution; anomalies were obtained by subtracting the 10year monthly average from 1984 and 1993. The monthly anomaly in sea level was estimated at the Sea Level Center by subtracting from each month the monthly average for the entire time series; this anomaly time series is the highest quality data product available. Chlorophyll concentrations from the CZCS were used to illustrate the biological impact of the El Niño conditions during the 1982-1983 event.

[11] SSH was measured by the T/P altimeter for the study period from 1996 to 1999 . At each data point the time average height measurement from 1993 to 1996 was subtracted to eliminate the marine geoid. This also removes the mean SSH and alongshore transport, leaving "residual" values that include all temporal variability (including seasonal cycles), while eliminating the temporal mean. The chosen base years include a multiyear period without strong El Niño effects. These data were used to estimate the coastal SSH within $75 \mathrm{~km}$ of the coast and the alongshore geostrophic transport residual within the $150-\mathrm{km}$ band adjacent to the coast.

[12] Satellite measurements of wind speed and direction were acquired from three different sensors: ERS-1 (January-September 1996), NSCAT (October 1996 to June 1997), and ERS-2 (July 1997 to December 1999). We used monthly averaged gridded data, which had been remapped onto a $1^{\circ}$ grid in the case of ERS and to a $0.5^{\circ}$ grid for NSCAT. The alongshore component of the wind was calculated from the angle of the coastline and the wind vector. Alongshore wind stress and the offshore Ekman transport, which is the primary indicator of upwelling, were then estimated using bulk formulae [Gill, 1982].

[13] The AVHRR Pathfinder Project provided the 9-km resolution SST product between January 1996 and December 1999. A monthly average was estimated from all available passes. This is the preferred SST data product because of its high spatial resolution (and temporal resolution, though here we used monthly means). It is not available prior to 1986 so we could not use it for the longer timescale context. A 10-year climatological monthly average was constructed with data from 1984 to 1993 to calculate anomalies. This base period (the same as used for the larger-scale SST product) was chosen because it has few major events. An index of upwelling strength, $\Delta \mathrm{SST}$, was estimated by subtracting the SST measured at a box $500 \mathrm{~km}$ offshore from the SST of the box adjacent to the coast at the same latitude $\left(\Delta \mathrm{SST}=\mathrm{SST}_{\text {coast }}-\mathrm{SST}_{\text {offshore }}\right)$ [Wooster et al., 1976; Parrish et al., 1983; Nykjaer and Van Camp, 1994; Hill et al., 1998]. Negative values occur when coastal SST is colder than that of the open ocean and indicate upwelling.

[14] Chlorophyll concentrations were measured by the OCTS between November 1996 and June 1997 and by SeaWiFS between September 1997 and December 1999; in both cases the monthly average standard mapped images at $9-\mathrm{km}$ resolution were used. We used the third reprocessing of SeaWiFS and the SIMBIOS-NASDA version of OCTS. This version of OCTS was processed with atmospheric correction algorithms identical to those used for SeaWiFS data, using ancillary meteorological and ozone data for the OCTS mission period. The algorithm for chlorophyll concentration is also similar to that for SeaWiFS: it was fit to data in the SeaBAM database corresponding to OCTS band passes and vicarious calibration was accomplished with data from the Marine Optical Buoy (MOBY). The comparison presented here assumes that observed differences between OCTS- and SeaWiFS-measured chlorophyll concentrations are geophysical. The used OCTS product is as similar as possible given nonconcurrent sensors with different attributes.

[15] Anomalies were estimated for SST and residuals for T/P SSH using different base periods. However, the impact of using different base periods has only a minor effect on the results since the El Niño is the dominant signal.

[16] Satellite data quality is not optimal in coastal areas compared to the open ocean. Measurement of SSH, SST, chlorophyll concentration, and wind speed suffer from the close proximity of land, which presents very different optical and microwave characteristics. Additional difficulties ensue for ocean color measurements, related to the optical properties of substances unrelated to phytoplankton concentration (e.g., dissolved organic matter or resuspended sediment) as well as to the variable properties of the atmosphere over landmasses, which will affect the atmospheric correction. The Peru-Chile Current does not present Case 2 waters usually, although they are more likely during El Niño events due to increased rainfall and flooding. Here we consider the chlorophyll measurements to be qualitative and indicative of pattern. Wind measurements are considered valid beyond $25 \mathrm{~km}$ of the coast and the pixel shown here is representative of $1^{\circ}$ or $0.5^{\circ}$. The altimeter data should be considered representative of two bands of approximately $75 \mathrm{~km}$ width with $20-30 \mathrm{~km}$ gaps next to the coast. 
a

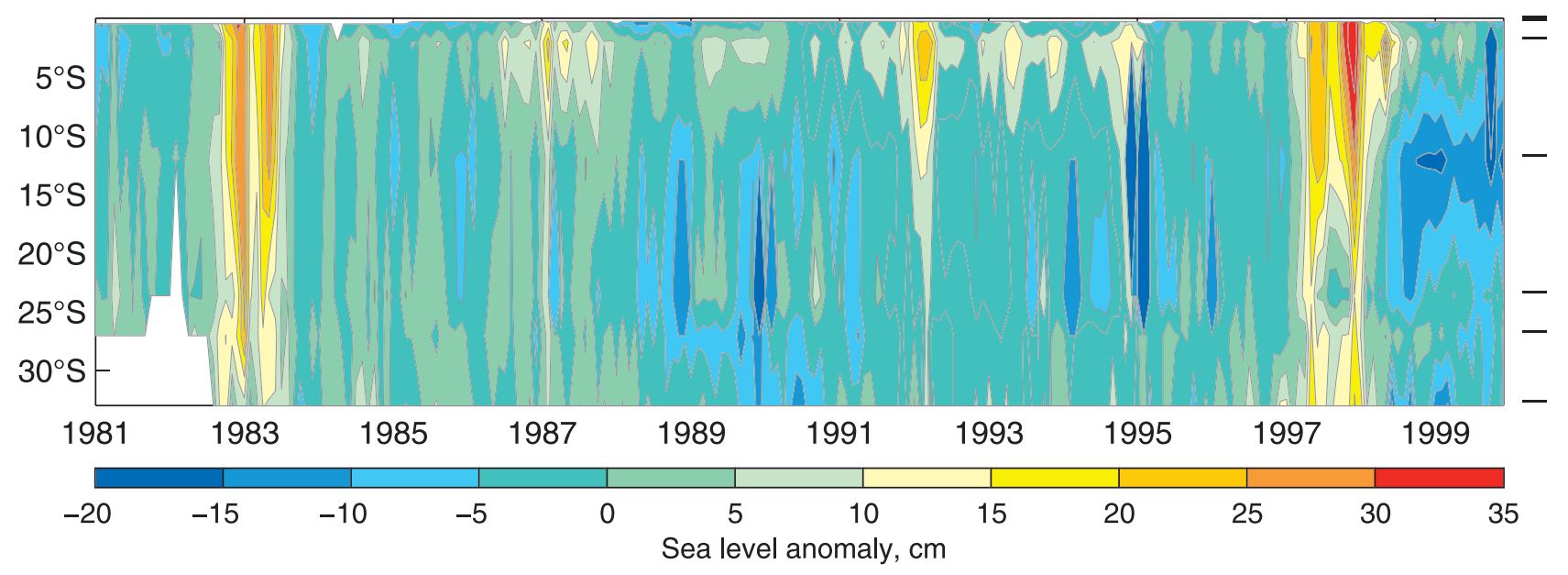

b

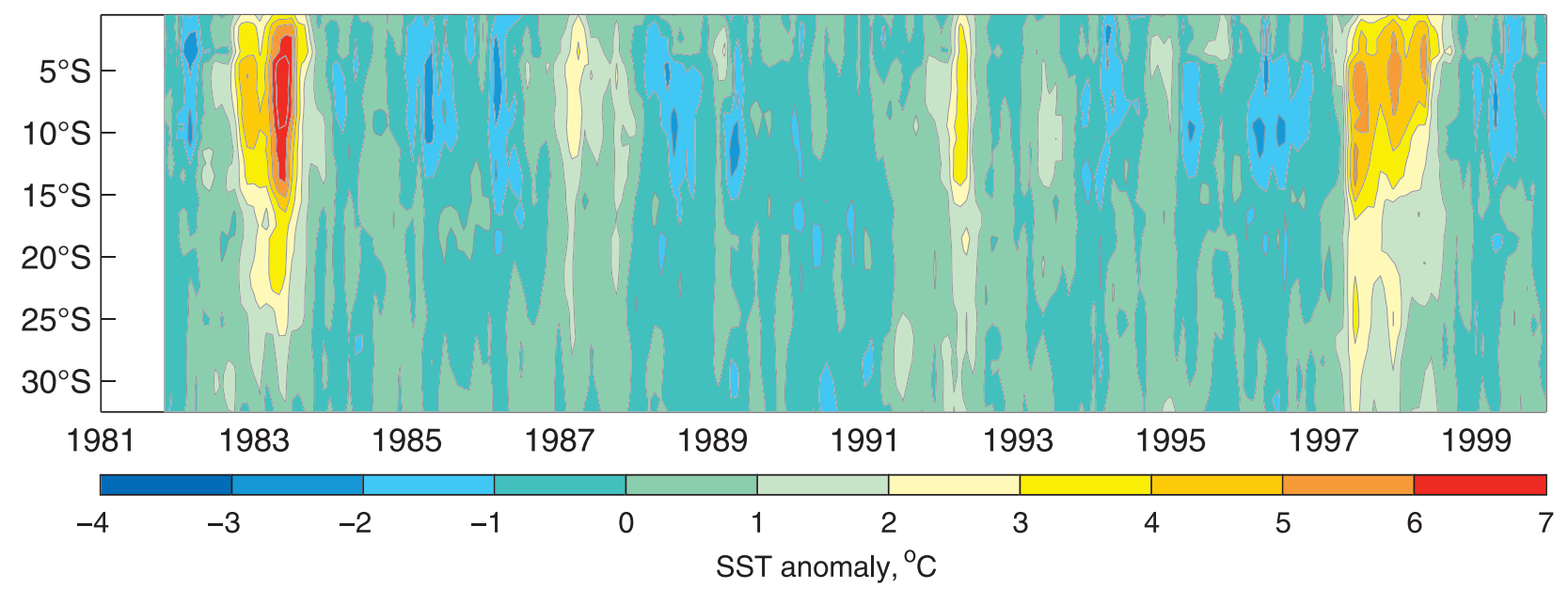

Figure 1. Sea level anomaly from tidal stations (a) and SST anomaly (b) along the west coast of South America between 1981 and 1998. The SST anomaly corresponds to the $1^{\circ}$ pixel adjacent to the coast.

Because of the relatively narrow shelf off Peru and Chile, the use of large bin averages diminishes the impact of problems due to coastal processes.

\section{Results}

\subsection{The Study Period Within a Longer Time Frame}

[17] Figure 1 shows the anomalies of the monthly average sea level and SST. The largest positive anomalies between 1981 and 1999 along the South American coast were the 1982-1983 and 1997-1998 El Niños: anomalies in sea level were almost $30 \mathrm{~cm}$ and those in SST exceeded $5^{\circ} \mathrm{C}$. During the La Niña event of 1998-1999 negative anomalies between -7 and $-14 \mathrm{~cm}$ extended between $5^{\circ} \mathrm{S}$ and $25^{\circ} \mathrm{S}$. Positive anomalies in 1987 and 1992 were less than $20 \mathrm{~cm}$ and $4^{\circ} \mathrm{C}$. The background anomalies tended to hover between $\pm 5 \mathrm{~cm}$ and $\pm 1{ }^{\circ} \mathrm{C}$; negative anomalies were smaller than the positive ones. The strongest negative anomalies (exceeding $-5 \mathrm{~cm}$ and $-2^{\circ} \mathrm{C}$ ) generally occurred north of $15^{\circ} \mathrm{S}$.

[18] Restricting the time frame to our study period (1996-1999) allows more direct comparison of the tide gauge sea level and SST (Figure 2). Anomalies in sea level and SST were negative throughout 1996. Though peak SST anomalies in 1996 were comparable to those in 1998-1999 $\left(\sim-2^{\circ} \mathrm{C}\right)$, the sea level anomalies in 1996 were not as strong as those at the end of the study period. Onset of positive anomalies for both variables during El Niño occurred approximately in March 1997. Anomalies were maximum $\left(>14 \mathrm{~cm}\right.$ and $\left.>2^{\circ} \mathrm{C}\right)$ north of $15^{\circ} \mathrm{S}$. The El Niño event appeared as two main peaks in sea level $(>14 \mathrm{~cm})$ and SST $\left(>4^{\circ} \mathrm{C}\right)$ in June-August 1997 and November 1997 to January 1998, with a relaxation period from August to October 1997. Following a relative relaxation period in February-March 1998, a third maximum with weaker meridional extent occurred in May 1998. Using the zero contours as a guide, the first two maxima started sooner in sea level than in SST. Anomalies surpassed $7 \mathrm{~cm}$ from the equator to $35^{\circ} \mathrm{S}$ in the first peak and $14 \mathrm{~cm}$ to $25^{\circ} \mathrm{S}$ in the second maximum. The first peak in SST anomaly had the greatest meridional extent $\left(>2^{\circ} \mathrm{C}\right.$ beyond $\left.30^{\circ} \mathrm{S}\right)$. A return to normal conditions began as early as February 1998 between $25^{\circ} \mathrm{S}$ and $30^{\circ} \mathrm{S}$. By August 1998, sea level and SST anomalies 
a
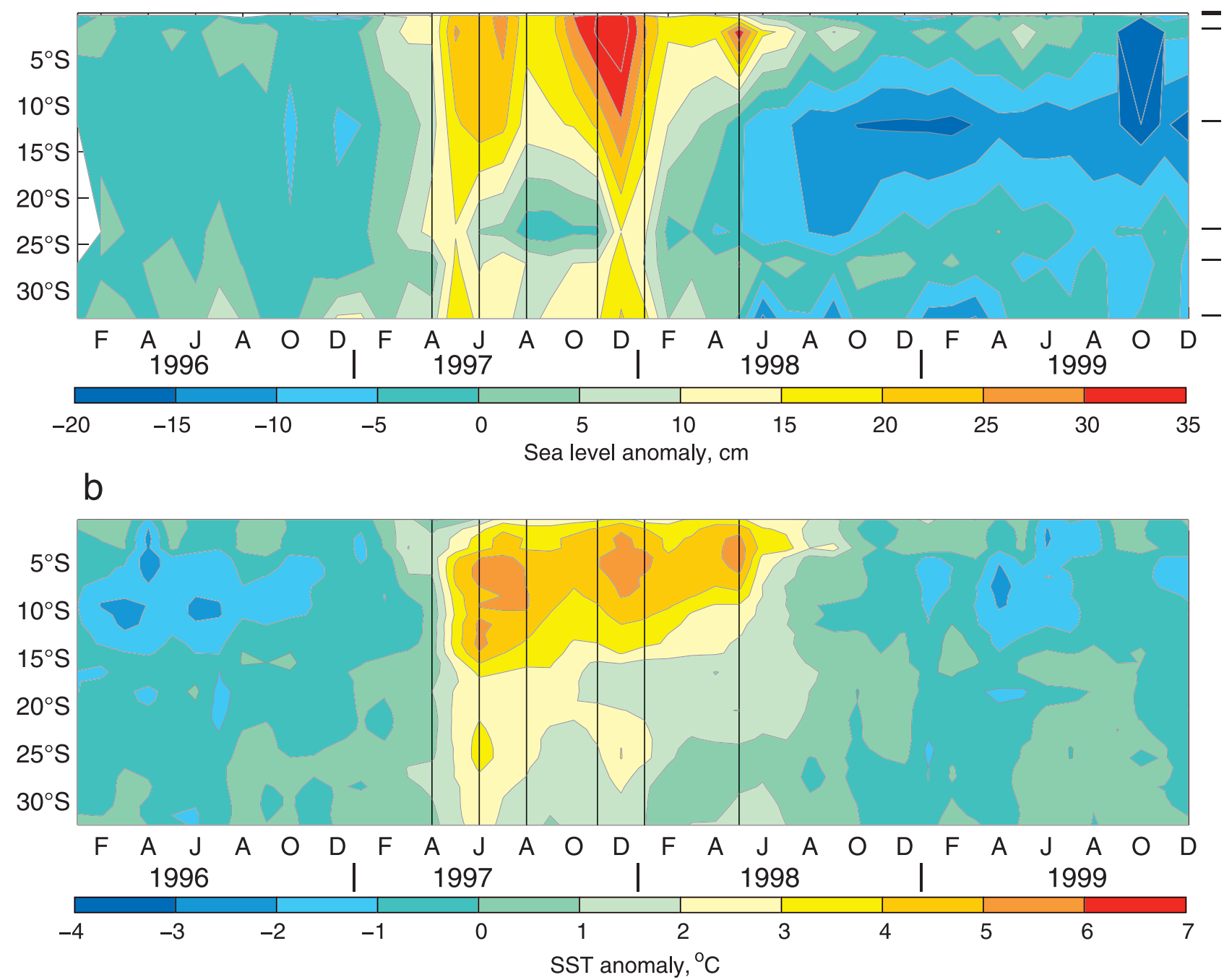

Figure 2. Sea level anomaly from tidal stations (a) and SST anomaly (b) along the west coast of South America between 1996 and 1998. The vertical lines mark April 1997, June 1997, August 1997, November 1997, January 1998, and May 1998. The Reynolds SST anomaly corresponds to the $1^{\circ}$ pixel adjacent to the coast.

were negative between $2^{\circ} \mathrm{S}$ and $30^{\circ} \mathrm{S}$, corresponding to La Niña conditions. Peak negative anomalies in sea level $(<21$ $\mathrm{cm})$ were observed after August 1998 between $2^{\circ} \mathrm{S}$ and $20^{\circ} \mathrm{S}$, although they were anomalously low along the entire coastline (save isolated positive values north of $5^{\circ} \mathrm{S}$ ) until the end of 1999 . Weak negative SST anomalies $\left(0^{\circ} \mathrm{C}\right.$ to $-1^{\circ} \mathrm{C}$ ) extended beyond $30^{\circ} \mathrm{S}$ from August 1998 to December 1999 .

\subsection{Seasonal and Interannual Variability in Upwelling}

[19] Three variables are proxies of upwelling intensity. The offshore transport calculated from scatterometer winds is a measure of the wind-induced upwelling; negative values of $\Delta \mathrm{SST}$ index reflect the presence of colder water adjacent to the coast; and the chlorophyll concentration represents the biological response to changing surface nutrient concentrations. To simplify the observed variability we have averaged the temporal evolution of the three upwelling- related variables in latitude bands that present consistent seasonal cycles and extent of impact of the anomalous conditions: north central Peru, north of $15^{\circ} \mathrm{S}$; southern Peru-northern Chile, $15^{\circ}-25^{\circ} \mathrm{S}$; central Chile, $25^{\circ}-35^{\circ} \mathrm{S}$; and south central Chile, $35^{\circ}-42^{\circ} \mathrm{S}$ (Figure 3 ).

[20] In general terms, Ekman transport was maximum in the region north of $15^{\circ} \mathrm{S}$ (Figure 3a), followed closely by that in south central Chile in austral spring and summer (Figure $3 \mathrm{j}$ ). Wind forcing between $15^{\circ} \mathrm{S}$ and $25^{\circ} \mathrm{S}$ was very weak and had a poorly defined seasonal cycle (Figure 3d), while it increased between $25^{\circ} \mathrm{S}$ and $35^{\circ} \mathrm{S}$, though the seasonal cycle remained weak. The winter minimum of wind forcing south of $35^{\circ} \mathrm{S}$ results from strong winds alternating in sign during storms. (Figure $3 \mathrm{j}$ ). The spatial distribution of $\Delta$ SST was similar, with maximum values in the northernmost $\left(-6^{\circ} \mathrm{C}\right)$ and southernmost regions $\left(-4^{\circ} \mathrm{C}\right)$, while $\Delta$ SST in the central two regions did not surpass $-3^{\circ} \mathrm{C}$ (Figures 3b, 3f, 3h, and 3k). Increasing latitude saw lesser 

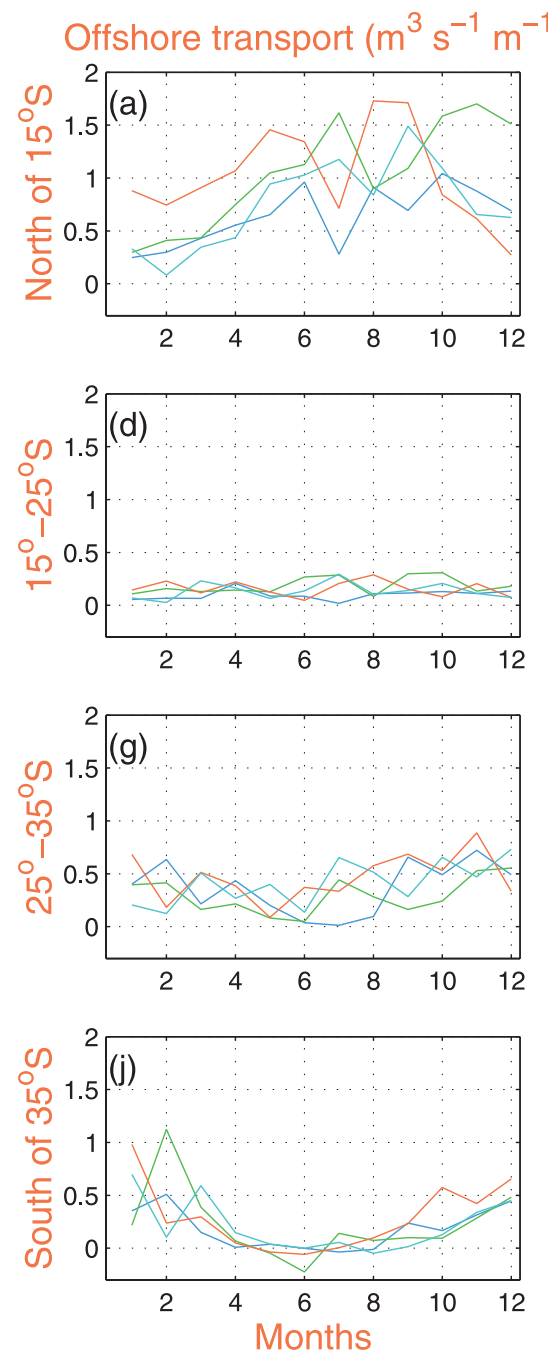
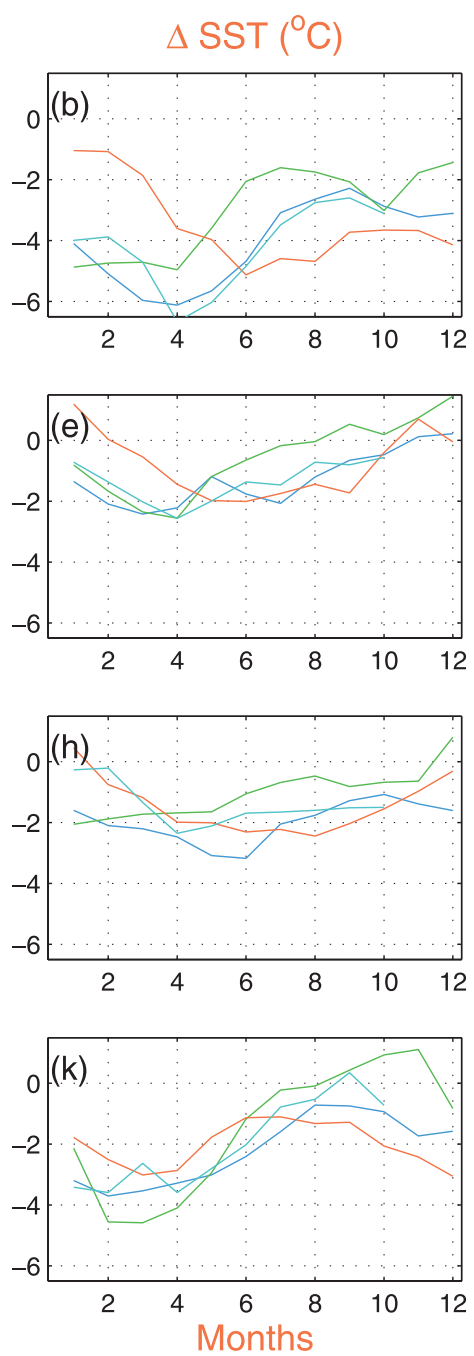
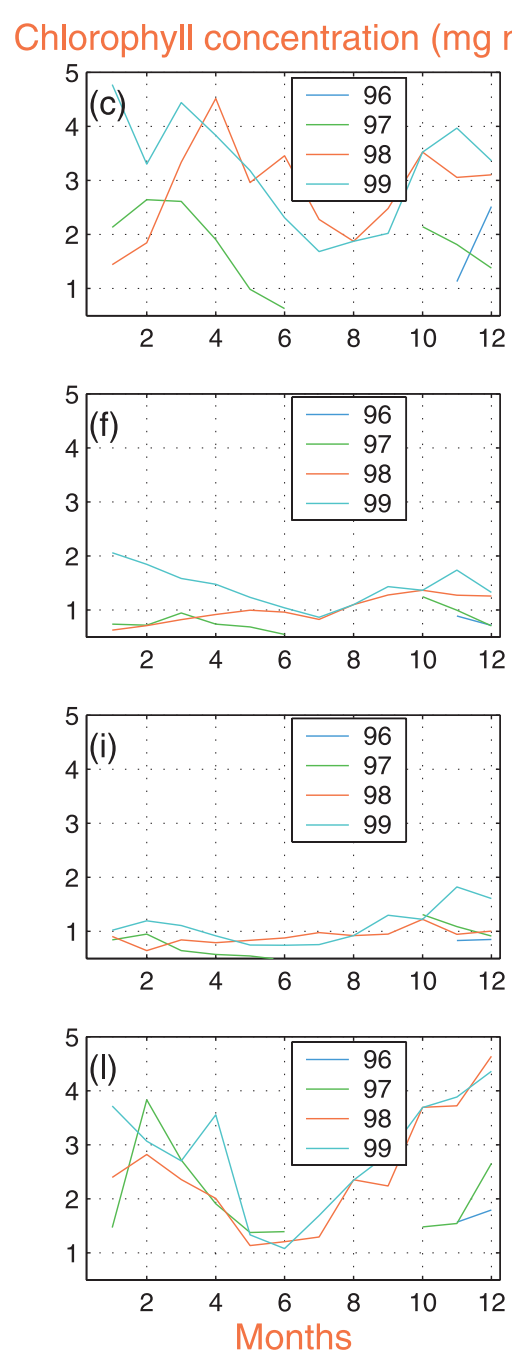

Figure 3. Latitude-averaged offshore Ekman transport (left column), $\Delta$ SST (middle column), and chlorophyll concentration (right column) for north of $15^{\circ} \mathrm{S}$ (top row), between $15^{\circ}$ and $25^{\circ} \mathrm{S}$ (middle row), between $25^{\circ}$ and $35^{\circ} \mathrm{S}$ (third panels), and between $35^{\circ}$ and $42^{\circ} \mathrm{S}$ (bottom row). The variables correspond to averages adjacent to the coast corresponding to $0.5^{\circ}-1^{\circ}$ for Ekman transport and $36 \mathrm{~km} \mathrm{(4}$ pixels running averaged along the coast) for $\Delta \mathrm{SST}$ and chlorophyll concentration.

impact of El Niño in the $\triangle$ SST during late 1997 and early 1998. Chlorophyll concentrations were likewise maximum $\left(1-4 \mathrm{mg} \mathrm{Chl} \mathrm{m}^{-3}\right)$ north of $15^{\circ} \mathrm{S}$ (Figure $3 \mathrm{c}$ ), and south of $35^{\circ} \mathrm{S}$ (Figure 31 ). Between $15^{\circ} \mathrm{S}$ and $35^{\circ} \mathrm{S}$ both the magnitude and the amplitude of the seasonal cycle of chlorophyll concentration were minimum, $0.5-2 \mathrm{mg} \mathrm{Chl} \mathrm{m}^{-3}$ (Figures $3 \mathrm{f}$ and $3 \mathrm{i})$. In all regions maximum values were observed in 1999.

\subsubsection{North Central Peru}

[21] Ekman transport $\left(0.2-1.7 \mathrm{~m}^{2} \mathrm{~s}^{-1}\right)$ was maximum here, peaking in austral winter (July-September) (Figure 3a). From October 1997 to October 1998 (El Niño conditions) wind forcing increased. Maximum $\Delta \mathrm{SST}$ occurred in the first half of the year (February to May-June), except for 1998 (Figure 3b). Minimum values occurred between June 1997 and May 1998. Chlorophyll concentrations reflected $\triangle \mathrm{SST}$, with minima from June to September (austral winter) of all years (Figure 3c) in spite of peak wind forcing, likely reflecting advective loss. Concentrations were lower in

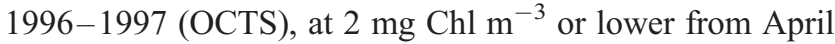
1997 to February 1998.

\subsubsection{Southern Peru-Northern Chile}

[22] The wind forcing was weakest $\left(0.05-0.3 \mathrm{~m}^{2} \mathrm{~s}^{-1}\right)$ in this region and did not show either a clear seasonal cycle or interannual variability. $\triangle \mathrm{SST}$ (Figure $3 \mathrm{e}$ ), was maximum between February and May (austral summer-fall) and changed sign late in the year (October-January). Under El Niño conditions $\Delta$ SST was positive (no upwelling) from August 1997 to February 1998. Chlorophyll concentrations were fairly homogeneous throughout the year with a slight minimum in austral winters (Figure 3f). The lowest concentrations on record were observed from January to May 1998 (El Niño), concurrent with weak $\Delta$ SST, and in 1997 (OCTS) although $\triangle$ SST was maximum during the first half of 1997 pre-El Niño.

\subsubsection{Central Chile}

[23] The offshore Ekman transport $\left(\sim 0.5 \mathrm{~m}^{2} \mathrm{~s}^{-1}\right)$ presents a slight maximum in austral spring and weak 


\section{COASTAL VARIABLES 1996-1999}
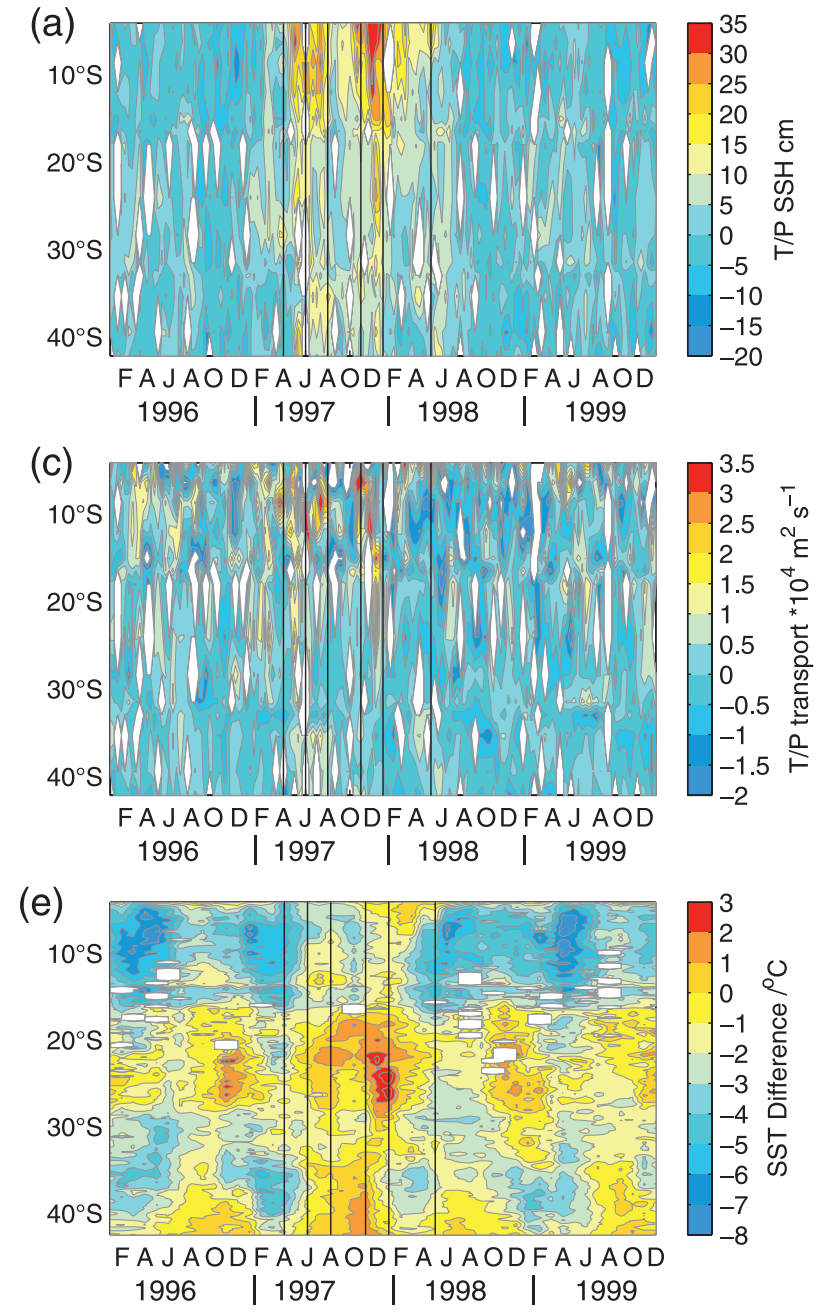

(b)

(d)

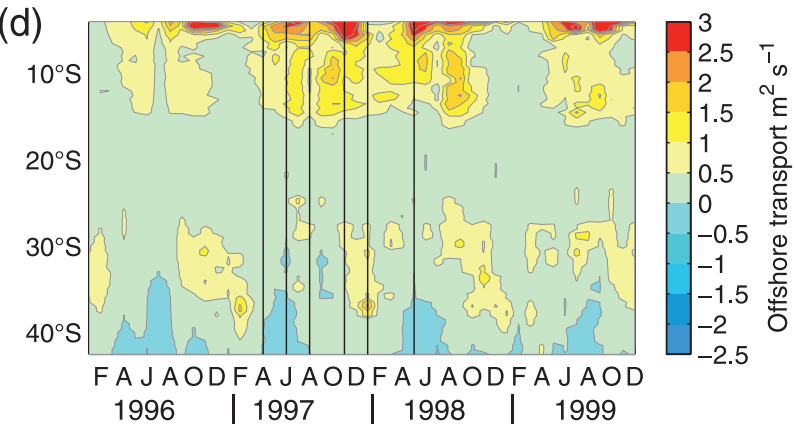

(f)
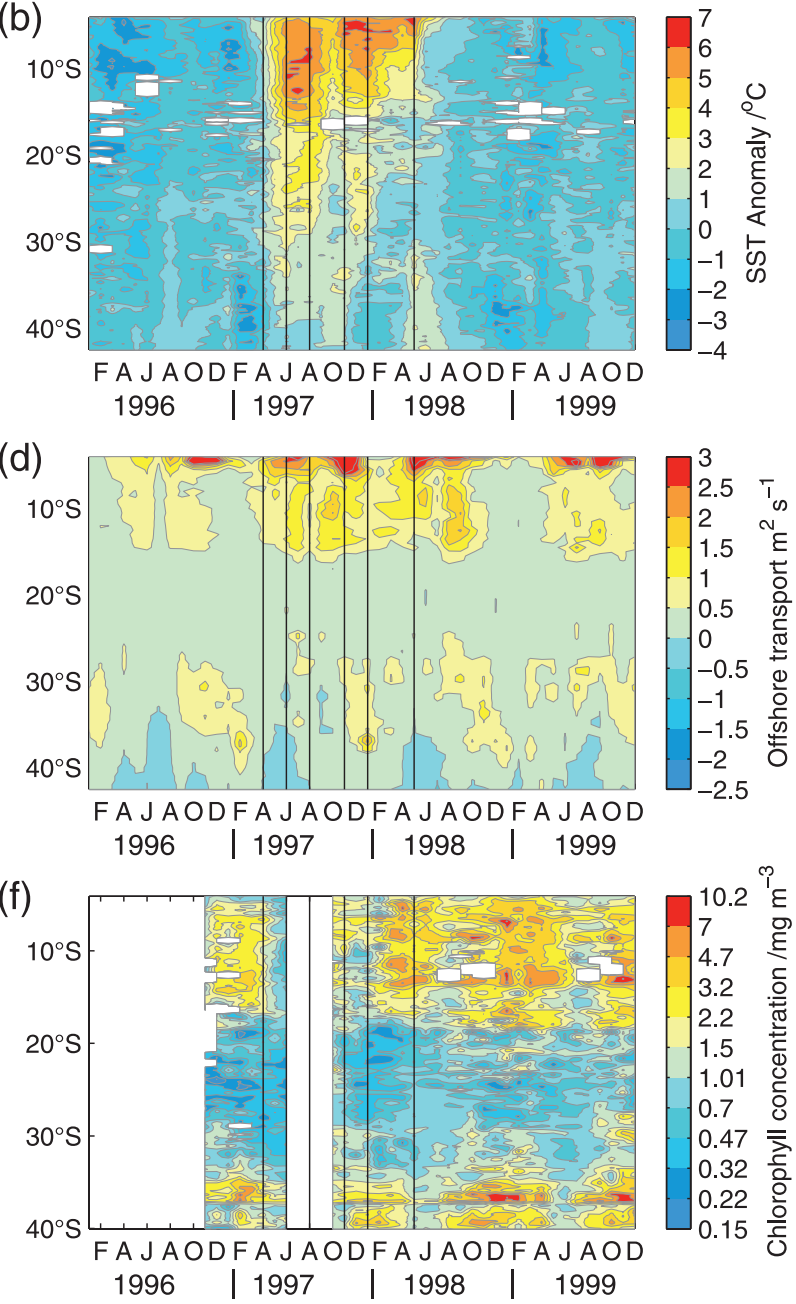

Figure 4. Hoffmuller diagram of variables along the coast: SSH anomaly from T/P (a), SST anomaly (b), alongshore transport residual estimated within $150 \mathrm{~km}$ of the coast estimated from T/P (c), offshore Ekman transport (d), $\Delta$ SST (e), and chlorophyll concentration (f). The vertical lines mark April 1997, June 1997, August 1997, November 1997, January 1998, and May 1998. The variables correspond to averages adjacent to the coast corresponding to $75 \mathrm{~km}$ for SSH and to $150 \mathrm{~km}$ for the alongshore transport, $0.5^{\circ}-1^{\circ}$ for Ekman transport, and $36 \mathrm{~km}$ (4 pixels running averaged along the coast) for SST anomaly, $\triangle \mathrm{SST}$, and chlorophyll concentration.

interannual variability (Figure $3 \mathrm{~g}$ ). $\Delta \mathrm{SST}$ was largest from April to June with minima from November to January (Figure 3h). December 1997 and January 1998 were positive, reflecting the second El Niño maximum. Chlorophyll concentrations were similar in magnitude and seasonality to those in northern Chile (Figure 3i).

\subsubsection{South Central Chile}

[24] This region presented the maximum seasonal range of upwelling intensity, $\sim 1 \mathrm{~m}^{2} \mathrm{~s}^{-1}$ in January-March to $-0.2 \mathrm{~m}^{2} \mathrm{~s}^{-1}$ between May and August (Figure 3j), with minimal interannual variability. The low monthly mean magnitudes in austral winter mask the occurrence of strong winds with alternating signs during storms. $\triangle \mathrm{SST}$ peaked between February and April and was minimum in August (Figure 3k). $\Delta$ SST in late 1997 and early 1998 was reduced compared to the other years. Chlorophyll was maximum
September-April (austral spring-summer) for all years, with a clear minimum in June (Figure 31), following the wind forcing instead of $\triangle \mathrm{SST}$.

\subsection{Evolution of Oceanographic Conditions}

[25] To explore the evolution of oceanographic conditions we present Hoffmuller diagrams of SSH, SST anomaly, the residuals of alongshore geostrophic flow (where the temporal mean has been removed), offshore Ekman transport estimated from wind, $\Delta \mathrm{SST}$, and chlorophyll concentration. SSH, anomaly of SST, and geostrophic flow directly reflect El Niño forcing by indicating increased sea level and SST, and poleward circulation [Strub et al., 1998]. T/P SSH (Figure 4a) was similar, though noisier, to the tide gauge signal (Figure 2a) in timing and magnitude, especially during the El Niño event. T/P measured a more pronounced 


\section{CHLOROPHYLL CONCENTRATION 1996-1999}
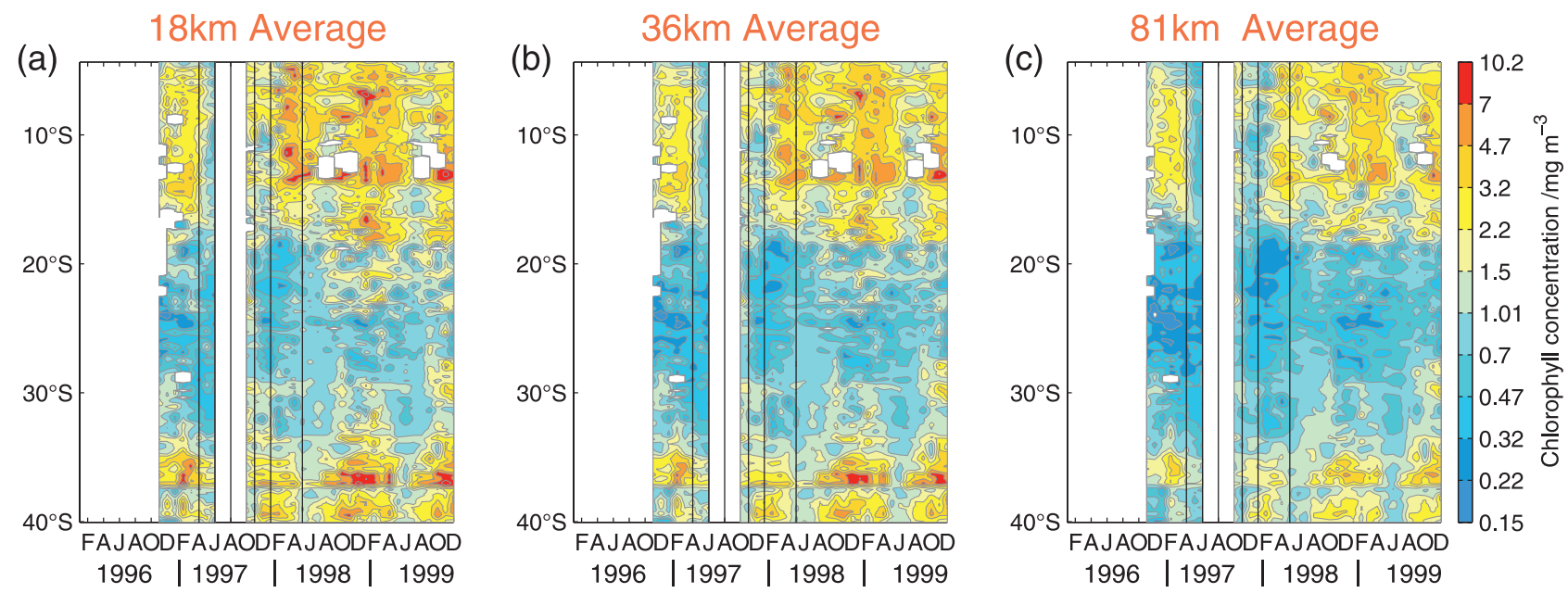

Figure 5. Comparison of the estimate of nearshore chlorophyll evolution averaged over different areas: $18 \times 18 \mathrm{~km}$ average (a), $36 \times 36 \mathrm{~km}$ average (b), and $81 \times 81 \mathrm{~km}$ average (c). The vertical lines mark April 1997, June 1997, August 1997, November 1997, January 1998, and May 1998.

relaxation period between the two maxima. After August 1998, SSH was not as anomalously low as was measured from the tide gauge. The Pathfinder SST anomaly (Figure 4b) was also comparable to the coarser resolution blended SST (Figure $2 \mathrm{~b}$ ) but presented more structure and more extreme values, as expected for a higher resolution product. Likewise, the satellite measure of alongshore transport centered approximately $110 \mathrm{~km}$ offshore (Figure $4 \mathrm{c}$ ) was also very variable.

[26] We break 1996-1999 into 3 major periods: La Niña (January 1996 to March 1997), El Niño (April 1997 to May 1998), and La Niña (June 1998 to December 1999); the El Niño period is in turn divided into smaller segments corresponding to the transition, first maximum, relaxation, and second maximum (Figures 4, 5, and 6).

\subsubsection{La Niña: January 1996 to April 1997}

[27] SSH (Figure 4a) and SST anomalies (Figure 4b) were generally negative (low sea level and cold) and transport residuals (Figure 4c) were primarily equatorward, with occasional poleward events (e.g., around March and June 1996). Ekman transport (Figure 4d) was offshore along the entire coastline north of $35^{\circ} \mathrm{S}$. Negative $\Delta \mathrm{SST}$ (Figure 4e) indicated that upwelling continued throughout the year. There were no measurements of chlorophyll concentration until November 1996 (Figure 4f). Concentrations surpassed $1 \mathrm{mg} \mathrm{Chl} \mathrm{m}{ }^{-3}$ from November 1996 to April 1997 north of $18^{\circ} \mathrm{S}$ and between $32^{\circ} \mathrm{S}$ and $38^{\circ} \mathrm{S}$. March 1997 , though subject to upwelling-favorable winds throughout the study domain, was a transition period to climatological SST and weakly positive SSH; weakly poleward flow residuals were observed north of $25^{\circ} \mathrm{S}$.

\subsubsection{El Niño: May 1997 to May 1998}

3.3.2.1. Transition (May-June 1997)

[28] Conditions changed dramatically after April 1997. The positive anomalies in SSH and SST rapidly reached 10 $\mathrm{cm}$ and $3^{\circ} \mathrm{C}$ between $4^{\circ} \mathrm{S}$ and $30^{\circ} \mathrm{S}$ (Figures $4 \mathrm{a}$ and $4 \mathrm{~b}$ ). The most extreme changes occurred north of $15^{\circ} \mathrm{S}$, where transport residuals became more consistently poleward (Figure 4c). Although offshore Ekman transport intensified or remained the same, $\Delta \mathrm{SST}$ decreased or changed sign, indicating that upwelling was not bringing cooler water from depth (Figures $4 \mathrm{~d}$ and $4 \mathrm{e}$ ). Chlorophyll concentrations responded to weaker nutrient supply, falling to $0.7 \mathrm{mg} \mathrm{Chl}$ $\mathrm{m}^{-3}$ or lower.

\subsubsection{First Peak (July-August 1997)}

[29] $\mathrm{SSH}$ exceeded $15 \mathrm{~cm}$ as far south as $40^{\circ} \mathrm{S}$, though anomalies were more pronounced and lasted longer between $5^{\circ} \mathrm{S}$ and $20^{\circ} \mathrm{S}$ (Figure 4a). Peak SST anomalies $\left(>2^{\circ} \mathrm{C}\right)$ started in June 1997 and extended to $30^{\circ} \mathrm{S}$ (Figure 4b). Positive values in transport, corresponding to poleward flow (Figure 4c), co-occurred with the peak sea level anomalies. Upwelling-favorable winds increased even further north of $15^{\circ} \mathrm{S}$ (Figure $4 \mathrm{~d}$ ) but the $\Delta \mathrm{SST}$ was $1-2^{\circ} \mathrm{C}$ weaker than in 1996 (Figure 4e). Unfortunately the interruption in satellite measurements of chlorophyll concentrations between July and September prevented observation of the first El Niño peak (Figure 4f).

\subsubsection{Relaxation (September-October 1997)}

[30] Positive anomalies in SSH and SST (Figures 4a and $4 b)$ decreased in this period. Relaxation was more pronounced and lasted longest between $10^{\circ} \mathrm{S}$ and $35^{\circ} \mathrm{S}$ (with anomalies below $5 \mathrm{~cm}$ and $2^{\circ} \mathrm{C}$ ) while anomalies remained greater than $5 \mathrm{~cm}$ and $4^{\circ} \mathrm{C}$ north of $10^{\circ} \mathrm{S}$. Geostrophic transport residuals were equatorward throughout most of the relaxation period (Figure 4c). Wind forcing decreased slightly in the entire domain (Figure 4d). By October 1997, concentrations exceeding $1 \mathrm{mg} \mathrm{Chl} \mathrm{m}^{-3}$ extended along the coastline (Figure 4f).

3.3.2.4. Second Peak (November 1997 to January 1998)

[31] The second SSH maximum was of greater magnitude $\left(>30 \mathrm{~cm}\right.$ to $10^{\circ} \mathrm{S}$ ) than the first maximum and SSH $>10 \mathrm{~cm}$ extended to $35^{\circ} \mathrm{S}$ (Figure 4a). Anomalous SSH and SST persisted between November 1997 and February 1998 to $30^{\circ} \mathrm{S}$ (SST) and $40^{\circ} \mathrm{S}$ (SSH) and to June 1998 north of $20^{\circ} \mathrm{S}$ (Figures $4 \mathrm{a}$ and $4 \mathrm{~b}$ ). SST anomalies did not extend as far south as those of SSH (Figure 4b). Geostrophic transport 


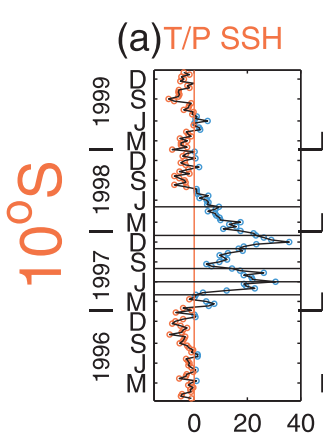

(e)

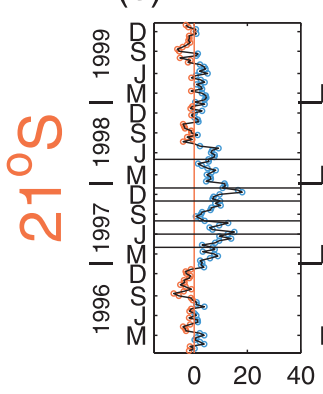

(i)
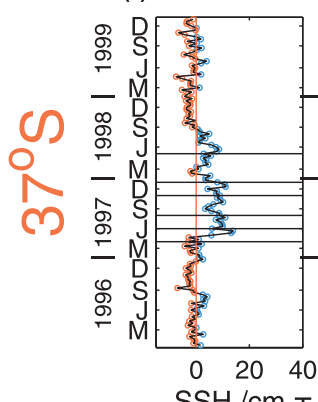

$\mathrm{SSH} / \mathrm{cm}$

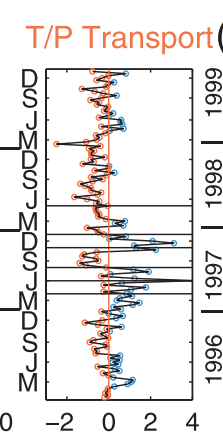

(b) SST Anomaly $\left({ }^{\circ} \mathrm{C}\right)$

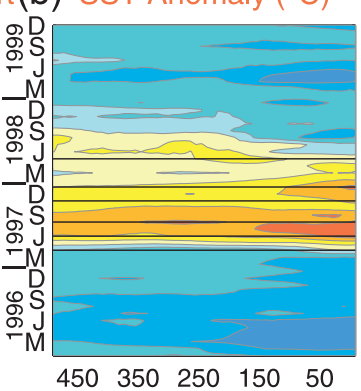

(f)
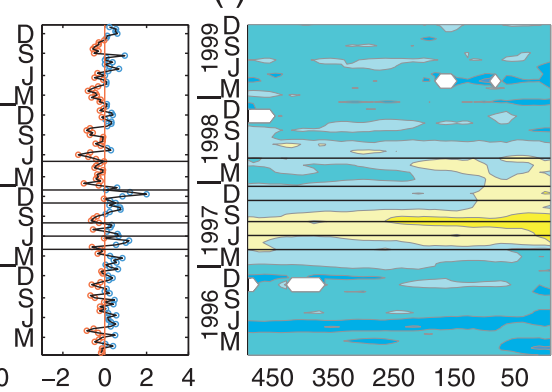

(j)

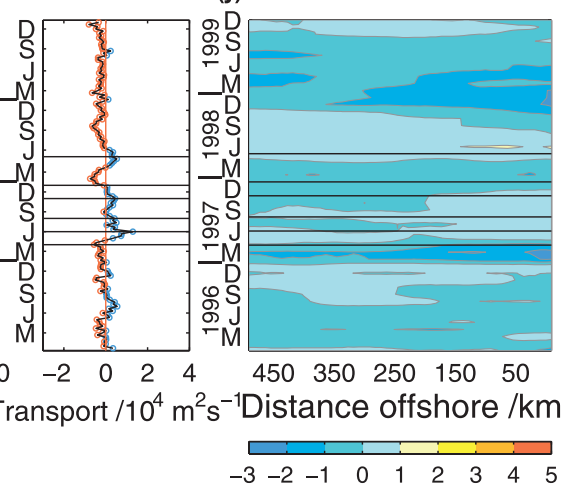

(c) $\quad \Delta \mathrm{SST}\left({ }^{\circ} \mathrm{C}\right)$

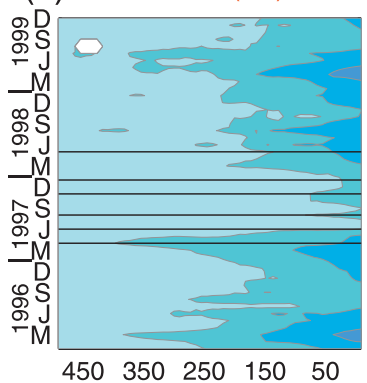

(g)

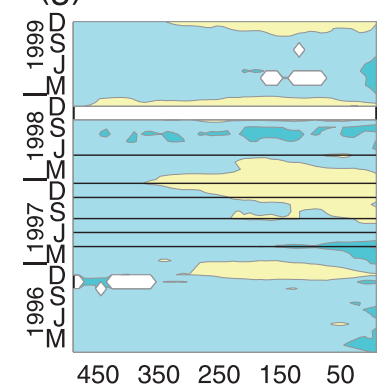

(k)

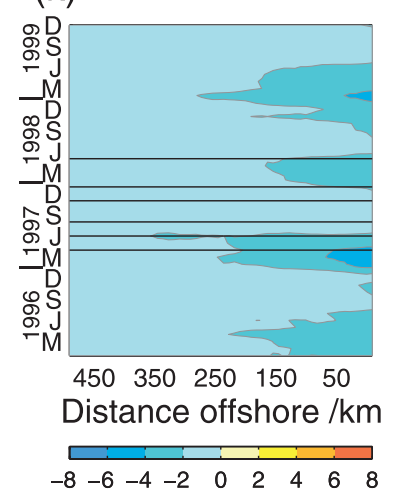

(d)Chlorophyll $\left(\mathrm{mg} \mathrm{m}^{-3}\right.$ )

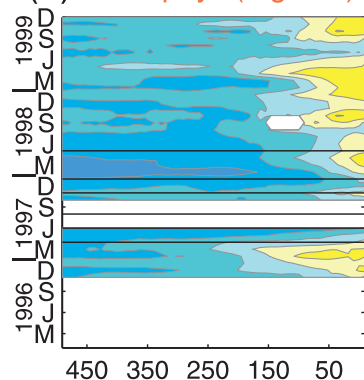

(h)

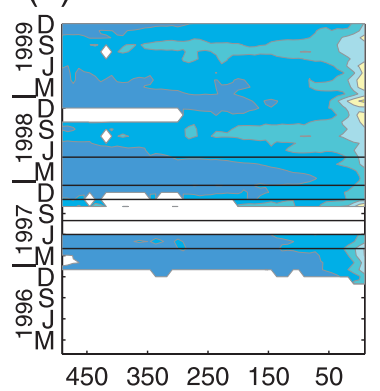

(l)

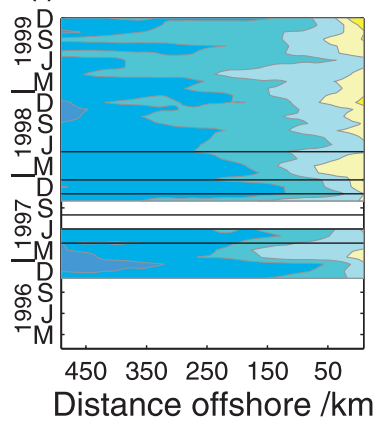

0.10 .1730 .5611 .83 .25 .710 .1

Figure 6. The integrated median height and transport residuals and evolution of environmental conditions, SST anomaly, $\triangle \mathrm{SST}$, and chlorophyll concentration along representative transects at characteristic locations: $10^{\circ} \mathrm{S}$ (top row), $21^{\circ} \mathrm{S}$ (middle row), and $37^{\circ} \mathrm{S}$ (bottom row). The horizontal lines mark April 1997, June 1997, August 1997, November 1997, January 1998, and May 1998.

residuals were poleward from December 1997 to February 1998 between $5^{\circ} \mathrm{S}$ and $25^{\circ} \mathrm{S}$, but were equatorward south of $7^{\circ}$ after February 1998 (Figure 4c). Upwelling-favorable winds were strong again north of $15^{\circ} \mathrm{S}$ (Figure $4 \mathrm{~d}$ ). This period presented the weakest $\Delta$ SST (Figure 4e) and chlorophyll concentrations in the entire record: Chlorophyll

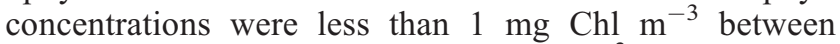
$10^{\circ} \mathrm{S}$ and $33^{\circ} \mathrm{S}$ and below $0.5 \mathrm{mg} \mathrm{Chl} \mathrm{m}{ }^{-3}$ between $18^{\circ} \mathrm{S}$ and $30^{\circ} \mathrm{S}$ (Figure 4f).

\subsubsection{Transition (February-May 1998)}

[32] SSH and SST anomalies remained positive $(0-10$ $\mathrm{cm}, 0-3^{\circ} \mathrm{C}$ ) from February to May 1998 , though maximum values were limited to north of $10^{\circ} \mathrm{S}$. Even though upwelling-favorable wind forcing weakened slightly, $\Delta$ SST started to change sign, indicating upwelling of cold water along the coast. Chlorophyll concentrations recovered rapidly after February 1998 to reach the highest values of the measuring period (Figures 3c, 3f, 3i, 31 and 4f).

\subsubsection{La Niña: June 1998 to December 1999}

[33] After August 1998 the SSH anomaly was predominantly negative, although as in 1996, the signal varied considerably (Figure 4a). The SST anomaly rapidly decreased after May 1998 and was less than $1{ }^{\circ} \mathrm{C}$ by August 1998 (Figure 4b). By September 1998, SST anomalies were negative, though less than in 1996. Peak negative anomalies in SSH and SST (exceeding $-5 \mathrm{~cm}$ and $-2^{\circ} \mathrm{C}$ ) occurred in March-June 1999 north of $10^{\circ} \mathrm{S}$ (Figures 4a and 4b). Geostrophic transport residuals were predominantly equatorward with positive values (poleward flow) between $20^{\circ} \mathrm{S}$ and $30^{\circ} \mathrm{S}$ from July to December 1998 (Figure 4c). Bursts of weak poleward transport occurred throughout 1999, especially north of $25^{\circ} \mathrm{S}$.

[34] Except for maxima in offshore wind forcing in June-August 1998 and 1999, the wind pattern was very similar to that of 1996 (Figures 4d, 3a, 3d, 3g, and 3j). $\Delta \mathrm{SST}$ indicated upwelling to $35^{\circ} \mathrm{S}$ from April to October 
1998 (Figure 4e). Between May and September 1998, coastal waters north of $38^{\circ} \mathrm{S}$ were $>1{ }^{\circ} \mathrm{C}$ cooler than offshore. Maximum $\triangle \mathrm{SST}$ exceeded $-3^{\circ}$ north of $10^{\circ} \mathrm{S}$. Upwelling intensity, as indicated by $\Delta \mathrm{SST}$, was not significantly greater than in 1996.

\subsection{Biological Impact of El Niño and La Niña Conditions}

[35] A comparison of the impact of the evolution of oceanographic conditions for the planktonic community can be addressed by changing the area over which we average chlorophyll concentrations: nominal 18, 36, and $81 \mathrm{~km}$ bins (Figure 5). Averaging over a larger area incorporates increasing offshore extent, which directly informs of the width of the high nutrient upwelling zone. El Niño conditions are generally accompanied by reduced width of the coastal band of high chlorophyll. Thomas et al. [2001b] found that the cross-shelf extent of high concentrations measured by SeaWiFS off northern Chile was directly affected by El Niño conditions and that it tracked SST patterns.

[36] Although chlorophyll concentrations decreased in the $18-\mathrm{km}$ bins (Figure 5a) concurrent with the SSH peaks, the decrease was much more substantial for larger averaging areas in this study as well (Figures $5 \mathrm{~b}$ and $5 \mathrm{c}$ ). Timing was also affected by the averaging: the decreased concentrations associated with the sea level maxima (and depressed nutricline) were seen earlier and lasted longer in the larger averaging bins (Figures 5a and 5c). Conversely, the relaxation period and the recovery to normal conditions were less pronounced and delayed in the larger-area average. The effect of decreasing chlorophyll concentrations associated with increased averaging area is particularly pronounced for northern Chile $\left(18^{\circ}-30^{\circ} \mathrm{S}\right)$ as the offshore extent of the upwelling front is minimum there.

\subsection{Evolution of Oceanographic Conditions Along Cross-Shelf Transects at Characteristic Locations}

[37] We choose characteristic locations along the coastline to understand the dynamics of each region. These locations are Peru at $10^{\circ} \mathrm{S}$, northern Chile at $21^{\circ} \mathrm{S}$, and south central Chile at $37^{\circ} \mathrm{S}$. These regions encompass the two maxima of chlorophyll concentration and offshore Ekman transport, and the relative minimum in northern Chile (Figure 3). By merging data from the $\mathrm{T} / \mathrm{P}$ tracks surrounding these characteristic locations, the residual median SSH and transport values reveal a more consistent pattern than seen in the Hoffmuller diagrams (Figures 4a and $4 \mathrm{c}$ ). We present the averaged SSH residuals within 75 $\mathrm{km}$ and geostrophic transport within $150 \mathrm{~km}$ of the coast together with offshore transects extending $500 \mathrm{~km}$ from the coast of SST anomaly, $\triangle \mathrm{SST}$ (calculated at each pixel $x$ as $\Delta \mathrm{SST}_{x}=\mathrm{SST}_{x}-\mathrm{SST}_{\text {offshore}}$ ), and chlorophyll concentration at the chosen latitudes (Figure 6).

\subsubsection{La Niña (January 1996 to April 1997)}

[38] SSH was predominantly negative, transport poleward, and SST was anomalously cold at all three locations until March 1997 (Figures 6a, 6b, 6e, 6g, 6i, and 6j). Between March and September 1996, negative SST anomalies exceeding $-2^{\circ} \mathrm{C}$ occurred within $150 \mathrm{~km}$ of the coast at $10^{\circ} \mathrm{S}$ (Figure $6 \mathrm{~b}$ ), and negative anomalies of more than $-1^{\circ} \mathrm{C}$ were found from the coast to $50 \mathrm{~km}$ at $21^{\circ} \mathrm{S}$ (Figure 6f). At $37^{\circ} \mathrm{S}$ the $\mathrm{SST}$ anomaly was between $0{ }^{\circ} \mathrm{C}$ and $-1^{\circ} \mathrm{C}$ for most of 1996 (Figure 6j). Maximum $\triangle \mathrm{SST}\left(<-1^{\circ} \mathrm{C}\right)$ extended at least $150 \mathrm{~km}$ from the coast between January and August 1996 at $10^{\circ} \mathrm{S}$ and $37^{\circ} \mathrm{S}$ (Figures 6c and 6k). There was a local minimum from September to November 1996 after which the $\triangle \mathrm{SST}$ reached maximum offshore extent in March 1997. At $21^{\circ} \mathrm{S}$ the cooler water was confined to $50-100 \mathrm{~km}$ offshore (Figure $6 \mathrm{~g}$ ). The effect of coastal upwelling extended $250-400 \mathrm{~km}$ offshore at $10^{\circ} \mathrm{S}$ and $37^{\circ} \mathrm{S}$ during "normal" conditions while at $21^{\circ} \mathrm{S}$ it was at most $200 \mathrm{~km}$ (Figures 6c, 6g, and 6k). Chlorophyll concentrations at $10^{\circ} \mathrm{S}$ and at $37^{\circ} \mathrm{S}$ surpassed $1 \mathrm{mg} \mathrm{Chl}$ $\mathrm{m}^{-3}$ within 150 and $50 \mathrm{~km}$ of the coast respectively in austral summer, while off northern Chile at $21^{\circ} \mathrm{S}$ maximum values were restricted to $10 \mathrm{~km}$ from shore (Figures $6 \mathrm{~d}, 6 \mathrm{~h}$, and 61$)$.

\subsubsection{El Niño (May 1997 to May 1998)}

[39] SSH was positive between May 1997 and August 1998. The two distinct maxima in June and December 1997 at the two northernmost sites were separated by a relaxation between September and October (Figures 6a and 6e). The amplitude and duration of the peaks (and the duration of the relaxation period) decreased moving south (Figures 6a, 6e, and 6i). Flow was predominantly poleward during the El Niño SSH maxima and predominantly equatorward during the relaxation period (September-October 1997). At all three sites, SST anomalies were positive between May 1997 and August-September 1998 (Figures 6b, 6f, and 6j) extending $500 \mathrm{~km}$ offshore. The magnitude of the positive anomaly decreased with increasing latitude (from $1^{\circ} \mathrm{C}$ to $>4^{\circ} \mathrm{C}$ at $10^{\circ} \mathrm{S}$, from $>0^{\circ} \mathrm{C}$ to $3^{\circ} \mathrm{C}$ at $20^{\circ} \mathrm{S}$, and less than $1^{\circ} \mathrm{C}$ at $37^{\circ} \mathrm{S}$ ). At $37^{\circ} \mathrm{S}$ anomalies were negative during the relaxation period. Upwelling, as evinced by negative $\triangle \mathrm{SST}$, continued between June 1997 and May 1998 at $10^{\circ} \mathrm{S}$; the offshore extent of cold water retreated from 400 to $150 \mathrm{~km}$ or less (Figure 6c). $\triangle \mathrm{SST}$ was positive (no upwelling) at $21^{\circ} \mathrm{S}$ and $37^{\circ} \mathrm{S}$ (Figure 6k).

[40] Chlorophyll concentrations in October 1997 were higher than in June 1996, but they rapidly fell to minimum values between December 1997 and February 1998 at $10^{\circ} \mathrm{S}$ $\left(\sim 1 \mathrm{mg} \mathrm{Chl} \mathrm{m}^{-3}\right)$ and $21^{\circ} \mathrm{S}\left(<0.3 \mathrm{mg} \mathrm{Chl} \mathrm{m}^{-3}\right)$ during the second peak of SSH (Figures $6 \mathrm{~d}$ and $6 \mathrm{~h}$ ). Minimum concentrations $\left(<1 \mathrm{mg} \mathrm{Chl} \mathrm{m}^{-3}\right)$ were observed at $37^{\circ} \mathrm{S}$ in June 1998. Very low values $\left(\sim 0.1 \mathrm{mg} \mathrm{Chl} \mathrm{m}^{-3}\right)$ were found offshore of $200 \mathrm{~km}$ at $10^{\circ} \mathrm{S}$ and beyond $100 \mathrm{~km}$ at $21^{\circ} \mathrm{S}$ in March 1998 (Figures 6d and 6h); such low values were not observed within $400 \mathrm{~km}$ of the coast at $37^{\circ} \mathrm{S}$ (Figure 61). After March 1998, nearshore concentrations began to exceed $>0.5 \mathrm{mg} \mathrm{Chl} \mathrm{m}^{-3}$ at all three locations.

\subsubsection{La Niña (June 1998 to December 1999)}

[41] This period saw a return to negative $\mathrm{SSH}$ and equatorward flow at all three locations (Figures 6a, 6e, and 6i). SST anomalies were negative throughout the three transects starting in January 1999, earlier near the coast (Figures 6b, $6 \mathrm{f}$, and $6 \mathrm{j}$ ). Maximum negative anomalies occurred at $10^{\circ} \mathrm{S}$ and $37^{\circ} \mathrm{S}\left(>-1^{\circ} \mathrm{C}\right)$; at $10^{\circ} \mathrm{S}$ they surpassed $-2^{\circ} \mathrm{C}$ in May 1999 within $150 \mathrm{~km}$ from the coast. After May 1999, anomalies abated at all three sites. Upwelling of cold water seemed to return to normal in June 1998, and by October 1998 SST values were larger than in 1996 in the two northernmost locations (Figures 6c and 6g). By May 1998 concentrations $>0.5 \mathrm{mg} \mathrm{Chl} \mathrm{m}{ }^{-3}$ extended $100 \mathrm{~km}$ offshore 
at $10^{\circ} \mathrm{S}$ and reached $200 \mathrm{~km}$ by September 1998, and they gradually occupied $\sim 50 \mathrm{~km}$ at $21^{\circ} \mathrm{S}$. At $37^{\circ} \mathrm{S}$ the band of

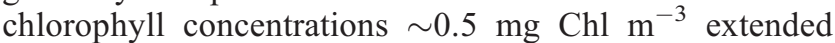
between 100 and $250 \mathrm{~km}$ after June 1998 (Figures 6d, 6h, and 61).

\section{Discussion}

[42] Remote sensing observations allow us to quantify the timeline, amplitude, and biological impact of oceanographic conditions from 1996 to 1999 off the western coast of South America, including the 1997-1998 El Niño event and the La Niña conditions preceding and following it. Here we relate aspects of these large-scale observations to the 19821983 El Niño event, to studies made on smaller spatial scales, and to observations along the west coast of North America.

\subsection{Comparison With the 1982-1983 El Niño in the Peru-Chile Current}

[43] The 1982-1983 El Niño was also preceded and followed by cool SSTs and low sea levels, although the negative anomalies were short-lived following the demise of the El Niño in 1983 compared to 1998 (Figures 2a, 2b, 7a, and $7 \mathrm{~b}$ ). The magnitude of the positive anomalies in SSH and SST was comparable to that of the 1997-1998 event (peak anomalies surpassing $25 \mathrm{~cm}$ and $6^{\circ} \mathrm{C}$ ). The alongshore extent of the anomalies was almost identical (beyond $30^{\circ} \mathrm{S}$ ). The duration of anomalously high SST and sea level was similar for the two events: in excess of 13-15 months. Likewise there was a relaxation period between the two maxima (January-March 1983). However, the timing was different: while the event in 1997-1998 went approximately from April to August, the 1982-1983 event started in August and lasted till November. Peak anomalies in sea level and SST occurred in December 1982 and May 1983 compared to July and December 1997. This shift in timing has an impact on the system response. Since the peak anomalies of the 1982-1983 event were in austral summer, when upwelling is maximum, rather than in winter, anomalies are potentially larger, as was in fact observed off northern Chile [Blanco et al., 2002] and Peru [Sánchez et al., 2000]. The transition to normal conditions was comparably quick but the 1982-1983 event was preceded and followed by only weak La Niña conditions; negative anomalies did not exceed $-5 \mathrm{~cm}$ or $-1^{\circ} \mathrm{C}$ except in isolated locations.

[44] CZCS coverage off the South American coast was very poor [Thomas et al., 1994] due to missing data (Figure 7c). A decrease in chlorophyll concentration can be discerned off the coast of Peru between October 1982 and August 1983 as well as off central Chile between April and August 1983. However, the data gaps make it impossible to make a quantitative comparison. Thomas et al. [1994] concluded from 8-month averages centered in winter and summer that CZCS pigment concentration was anomalously low in 1983 and 1984.

\subsection{Comparison With Higher Resolution, Regional Studies}

[45] In a study of the 1997-1998 El Niño off the coast of Peru $\left(2^{\circ}-18^{\circ} \mathrm{S}\right)$, Sánchez et al. [2000] qualify the event as extraordinary and of the same magnitude as that of 19821983 on the basis of data collected in routine cruises between September 1996 and October 1998. They identify two peaks in SST anomalies along the entire coastal band: a modest one in August 1997 and a strong one in January 1998, separated by a relaxation in October 1997. Positive anomalies persisted for a 16-month period in the north and a 13 -month period in the south. This timeline is consistent with satellite observations at monthly averaged timescale (Figures 2 and 4). Salinities indicate the intrusion of equatorial surface waters and subtropical surface waters as far south as $15^{\circ} \mathrm{S}$, a direct consequence of the poleward flow seen in Figures $4 \mathrm{c}$ and 6a. Surface concentrations of nitrate and oxygen were ultimately reduced reflecting the characteristics of upwelled water and the advection of equatorial and subtropical waters. Maximum perturbation in the surface fields of nitrogen and oxygen occurred between December 1997 and February 1998, coinciding with minimum chlorophyll concentrations measured by SeaWiFS in that 3-month period (Figures 4f, 5, and 6d). The vertical profiles reflected increased poleward flow and the maximum gradients in oxygen and nitrogen were deeper than usual: the nitracline went from 50 to $100 \mathrm{~m}$ and the oxicline from 30 to $>100 \mathrm{~m}$. The return to normal conditions occurred earlier in the south, starting in May 1998 and then moved northward, also consistent with observations reported here. The volume of net phytoplankton decreased notably and planktonic organisms typical of tropical waters became prevalent. Based on the increased depth of the nutricline and oxycline, Sánchez et al. [2000] propose that the 1997-1998 event may have had a greater impact than the $1982-1983$ event.

[46] Ulloa et al. [2001] analyzed a time series station in northern Chile (Antofagasta $23^{\circ} \mathrm{S}$ ) between June 1996 and January 1998. They record rapid onset of El Niño conditions in April 1997, followed by two periods of relative relaxation in June and August-September and followed by another maximum in November 1997. They conclude that the physical effects of El Niño had minor biological impact, as they found essentially no change in phytoplankton and zooplankton biomass averaged for non-El Niño and El Niño conditions. Since bulk measures do not always reflect shifts in community structure they chose to focus on a characteristic species of the region, Calanus chilensis. The zooplankter increased slightly in abundance and production, reflecting a likely benefit from the increased temperature and a lack of food limitation. In contrast to this result, satellite measurements of near-surface chlorophyll concentration, using both monthly 9-km data (Figures 4 and 5) and 8-day, 4-km resolution data [Thomas et al., 2001b], decreased unequivocally during El Niño and then increased. The results of Ulloa et al. [2001] come from a nearshore site in a semi-enclosed bay during the first part of the 1997 event. Thus they are consistent with the contention that the impact of El Niño is reduced in the nearshore region (Figure 5). Also averaging the concentrations during the peak sea level anomaly with that of the relaxation period will minimize the biological impact of El Niño forcing.

[47] Shaffer et al. [1999] presented results from a 6-year record of temperature and current speed and direction from a mooring at $30^{\circ} \mathrm{S}$ off Chile. Their sampling period ended in November 1997, thus capturing the 1995-1996 La Niña 
a
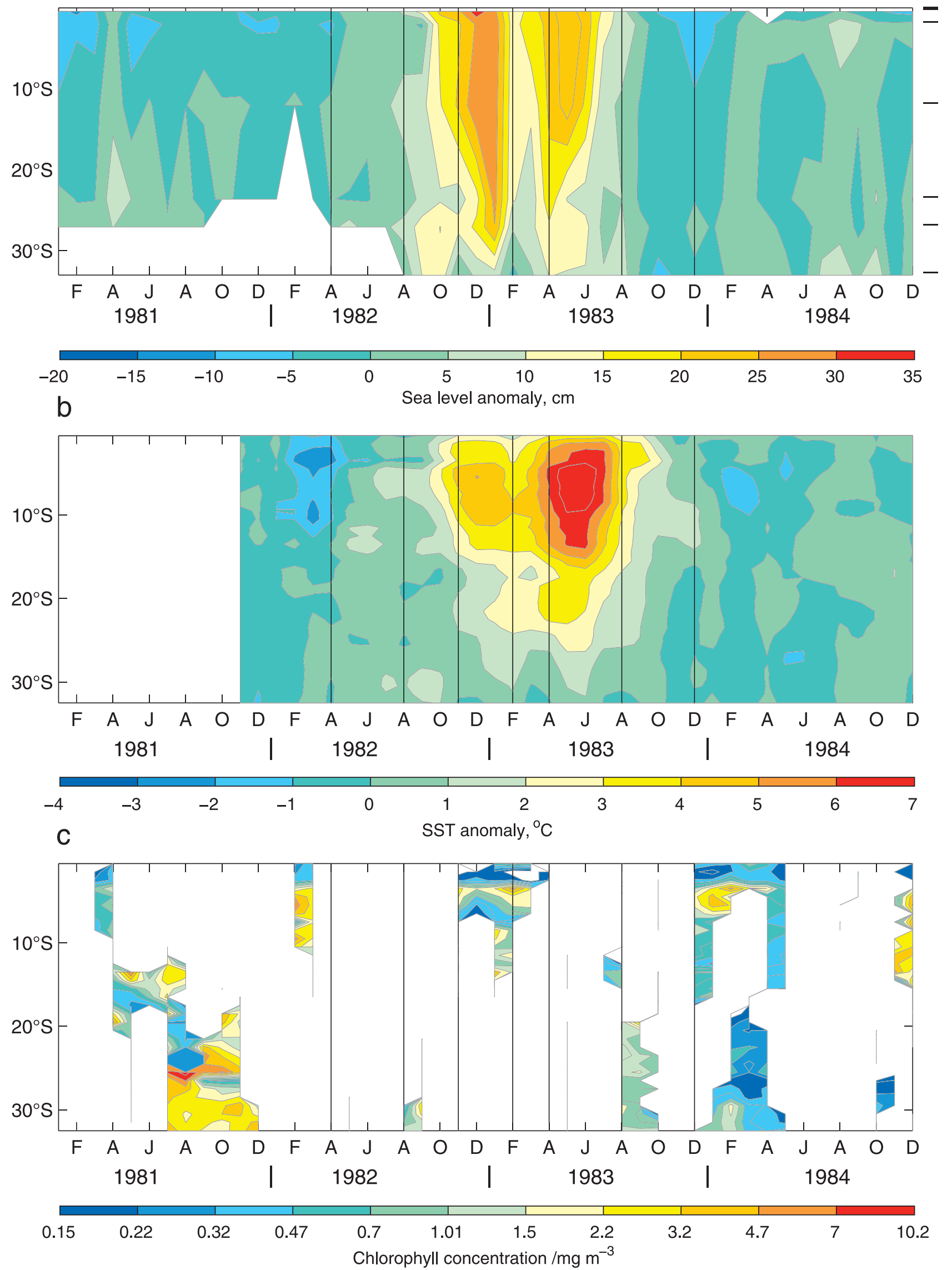
and the first part of the 1997-1998 El Niño event. They found that variability in flow was dominated by semiannual variations, with maximum intraseasonal variability associated with coastally trapped waves in austral summer and during El Niño events. They attribute the onset of warming in late 1996 to weaker winds in the vicinity of $30^{\circ} \mathrm{S}$, which they relate to atmospheric teleconnections with the western equatorial Pacific. This is consistent with our results. We found that the lowest alongshore wind speeds at $30.5^{\circ} \mathrm{S}$ of the 4-year time series were measured by ERS-1 in July 1996, by NSCAT between March and June 1997, and by ERS-2 in July-September 1997 (not shown). The Hoffmuller diagram of wind stress in the Peru-Chile Current from ERS-1 and ERS-2 in the study of Shaffer et al. [1999] reveals the same features as seen in Figure $4 d$ although we used NSCAT data when available.

[48] Blanco et al. [2002] carried out a detailed analysis of the evolution of hydrographic conditions between January 1996 and May 1998 for northern Chile between $18^{\circ} \mathrm{S}$ and $24^{\circ} \mathrm{S}$. A normal seasonal progression was observed from May 1996 to March 1997, although conditions were anomalously cool and fresh. Maximum anomalies in temperature and salinity $\left(2^{\circ} \mathrm{C}\right.$ and $\left.0.1 \mathrm{psu}\right)$ extended to $400 \mathrm{~m}$ depth in December 1997 within $50 \mathrm{~km}$ of the coast, although March 1998 presented the largest surface anomalies $\left(>4^{\circ} \mathrm{C}\right.$ and $\left.0.6 \mathrm{psu}\right)$. During the two sea level maxima, flow was poleward throughout the water column. Although SST had returned to the climatological mean by May 1998 and flow next to the coast was equatorward, offshore salinity remained anomalously high. Conditions off northern Chile returned to normal between August and December 1998. Alongshore winds measured at airports presented downwelling-favorable anomalies during the first half of the El Niño period at $20.5^{\circ} \mathrm{S}$ and for essentially the entire event at $18.5 \mathrm{~S}$. However, these anomalies did not lead to a reversal in direction of the wind, which was simply weaker. There was no clear decrease in offshore transport as measured by scatterometer in this region, but the remote sensing measurements are taken at least $25 \mathrm{~km}$ offshore due to problems with the shift in microwave return from land to ocean surface.

[49] Thomas et al. [2001b] used high resolution satellite measurements of SST and chlorophyll for the same region off northern Chile. They found that spatial patterns of chlorophyll closely tracked those of SST, indicating a strong link between biological response and upwelling. During the first peak in sea level anomalies (May 1997), they observed little effect on the cross-shore SST gradient, as it coincided with the onset of winter patterns. However, the second pulse in December 1997 was accompanied by reduced frontal structure, and both chlorophyll concentration and its offshore extent decreased. In March 1998, coastal chlorophyll concentrations exceeded $1 \mathrm{mg}$ Chl $\mathrm{m}^{-3}$ and values surpassing $0.5 \mathrm{mg} \mathrm{Chl} \mathrm{m}^{-3}$ extended 100 $\mathrm{km}$ offshore. This is consistent with our coarse resolution $(9 \mathrm{~km})$ transect at $21^{\circ} \mathrm{S}$ (Figure $6 \mathrm{~b}$ ) which showed concen-

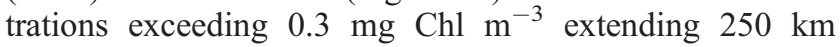

offshore from June to September 1998 and again in 1999 from June to September.

\subsection{Comparison With the 1997-1998 El Niño Event in the California Current}

[50] Several authors have studied the 1997-1998 event off the west coast of North America, both from an observational standpoint, using in situ observations [Hayward, 1999; Bograd and Lynn, 2001] or remote sensing information [Strub and James, 2002a, 2002b], and from a modeling perspective [Miller et al., 2000]. While the evolution of the 1997-1998 event off South America showed a clear relationship between conditions observed in the equatorial Pacific and with the expected time lag corresponding to the travel time of coastally trapped waves, the response was not as distinct off North America. El Niño can effect changes in oceanic conditions at midlatitudes via remote forcing (poleward advection of coastally trapped waves along the ocean boundary) and local forcing (decreased upwelling-favorable winds), each of which plays a different role in different locations [Strub and James, 2002a].

[51] Strub and James [2002a] found that the relative importance of local versus remote forcing increased with latitude. The link to the remote equatorial signal was greatest within $15^{\circ}-20^{\circ}$ of the equator while the effect of local winds on the timing of the signal was maximum at mid to high latitudes. They noted that the waveguide for coastally trapped waves is interrupted by topographic features, specifically the Gulf of California in the Northern Hemisphere and the change in coastline angle at $18^{\circ} \mathrm{S}$ off South America. Strub and James [2002a] conclude that changes associated with the 1997-1998 event were dominated within $15^{\circ}$ of the equator by the remote forcing signal, while further poleward, local wind forcing (which is related as well to El Niño forced changes in atmospheric circulation) was more important. The consistent signal in SST anomaly, $\triangle \mathrm{SST}$, and chlorophyll concentration north of $15^{\circ} \mathrm{S}$ presented here support this contention, as does the strongly wind-driven dynamics south of $35^{\circ} \mathrm{S}$.

[52] In 1997-1998, sea level increased gradually north of $16^{\circ} \mathrm{N}$ culminating in a single peak, corresponding to the second maximum observed off South America; this maximum occurred later in time and with decreased intensity at increasing latitudes [Hayward et al., 1999; Strub and James, 2002a]. Similarly to what was observed in the Peru-Chile Current under El Niño conditions, in the southern California Current System $\left(30^{\circ}-36^{\circ} \mathrm{N}\right)$ the coastal countercurrent was broader and stronger (i.e., increased poleward flow) and the mixed layer was deeper and warmer than usual [Hayward et al., 1999]. Increased poleward flow was observed in cruises from July 1997 to February 1998, when the event reached maximum impact [Hayward et al., 1999; Bograd and Lynn, 2001]. Dynamic height was anomalously high, the SST anomaly was $3-4^{\circ} \mathrm{C}$, poleward flow was enhanced, the nutricline was extraordinarily deep, and the biomass of phytoplankton and zooplankton were

Figure 7. (opposite) Sea level anomaly from tidal stations (a), SST anomaly (b), and pigment concentration from CZCS (c) along the west coast of South America between 1981 and 1984. The vertical lines mark April 1983, August 1983, November 1983, February 1984, August 1984, and December 1984. 
very low in February 1998 [Bograd and Lynn, 2001]. The return to normal conditions was rapid. By April 1998 dynamic height fell and the offshore gradient increased, nitracline depths of order $60 \mathrm{~m}$ extended almost $200 \mathrm{~km}$ offshore along a transect extending W-SW from $\sim 34^{\circ} \mathrm{N}$ (CalCOFI line 90), and chlorophyll concentrations were greater than $3.6 \mathrm{mg} \mathrm{Chl} \mathrm{m}^{-3}$ [Bograd and Lynn, 2001]. Onset of La Niña conditions occurred in April 1999, in which chlorophyll reached the maximum values found between 1996 and 1999. Increased zooplankton abundance predated that of phytoplankton by a few months, indicating processes independent of direct trophic control, such as advective transport of zooplankters or increased growth due to onset of stratification. Bograd et al. [2000] suggest that the high upwelling, highly productive conditions that started in April 1999 may signal the transition to a new North Pacific regime.

[53] The evolution of water properties from the El Niño to La Niña can be interpreted from temperature and salinity properties, available for the CalCOFI station at $\sim 33.5^{\circ} \mathrm{N}$ (station 90.30) [Hayward et al., 1999] in the southern California Current and for northern Chile at $20.5^{\circ} \mathrm{S}$ [Blanco et al., 2002]. During 1996, waters at $20.5^{\circ} \mathrm{S}$ were cooler and fresher than climatology and corresponded to conditions more like those observed at $23.5^{\circ} \mathrm{S}$. Starting in May 1997 and progressively thereafter, they came to resemble the warmer and more saline waters typically observed at $18.5^{\circ} \mathrm{S}$. In fact, near-surface waters were very similar to unmodified subsurface tropical water and below $100 \mathrm{~m}$ there was a strong influence of equatorial subsurface water, consistent with the enhanced poleward flow. The transition to La Niña conditions had started by May 1998, when surface waters were $\sim 5^{\circ} \mathrm{C}$ cooler than in March 1998. In the southern California Bight at $\sim 33.5^{\circ} \mathrm{N}$, the surface layer was anomalously warm in July and September 1997 and the entire water column was warmer than climatology between December and June 1998 [Hayward et al., 1999]. Salinity was anomalously high between July 1997 and May 1998, starting at depth and from December 1997 to April 1998 throughout the water column. By January 1999 there were no waters warmer than $15^{\circ} \mathrm{C}$, consistent with climatology, but in April 1999 La Niña conditions were indicated by surface waters $\sim 4^{\circ} \mathrm{C}$ colder than usual.

[54] A comparison of the vertical structure of the El Niño signal for the same CalCOFI site $(90.30)$ at $\sim 33.5^{\circ} \mathrm{N}$ and Iquique (Chile) at $20.5^{\circ} \mathrm{S}$ can be made from the studies of Thomas et al. [2001b] and Hayward et al. [1999]. For both locations there were cold anomalies in 1996, in the upper $200 \mathrm{~m}$ off California and throughout the water column off Chile. From July to September 1996, the water was anomalously warm below $200 \mathrm{~m}$ at the Chilean site and there was a doming of the zero anomaly isoline off California. Surface waters started to warm (positive anomalies) in January 1997 off California, though anomalously cold subsurface waters persisted between 50 and $100 \mathrm{~m}$ until June 1997. Temperature anomalies in the upper $400 \mathrm{~m}$ off Chile switched from negative to positive in January 1997. Maximum anomalies in California occurred from September 1997 to February 1998 , with values of $4^{\circ} \mathrm{C}$ between 50 and $100 \mathrm{~m}$ and of $2^{\circ} \mathrm{C}$ extending to $150 \mathrm{~m}$. By contrast in the Chilean site, the two peaks in sea level were accompanied by temperature anomalies greater than $2^{\circ} \mathrm{C}$ extending beyond $400 \mathrm{~m}$ in May 1997 and to $350 \mathrm{~m}$ between November and December 1997 , but maximum values were $\sim 6^{\circ} \mathrm{C}$ on the second peak and extended to $150 \mathrm{~m}$. Recovery to colder conditions in the California station occurred first at depth (between 200 and $500 \mathrm{~m}$ as early as May 1998) and throughout the water column by November 1998 and they remained order $-0.5^{\circ} \mathrm{C}$ for most of the water column and higher at shallow depths. Likewise, off Chile, the water column was cooler first below 150 m (between January and March 1998) while at the surface and from March to August 1998, the SST anomaly remained $\sim 0.5^{\circ} \mathrm{C}$ to $400 \mathrm{~m}$. The timing of the evolution of SST with depth was quite similar for the two sites but the positive anomalies were stronger, had greater penetration with depth, and persisted longer at $20.5^{\circ} \mathrm{S}$ than at $33.5^{\circ} \mathrm{N}$.

[55] The timing and magnitude of the changes in the temperature anomaly at $10 \mathrm{~m}$ along the CalCOFI line extending W-SW from $\sim 33.5^{\circ} \mathrm{N}$ [Bograd et al., 2000] resembled the progression of SST anomaly in time versus offshore distance at $21^{\circ} \mathrm{S}$ more than that observed at $37^{\circ} \mathrm{S}$ (Figures 6a and $6 \mathrm{~b}$ ). At both $21^{\circ} \mathrm{S}$ and $33.5^{\circ} \mathrm{N}$, peak positive anomalies $\left(2-3^{\circ} \mathrm{C}\right)$ took place between March 1997 and June 1998 , while a band of negative anomalies $\sim-1^{\circ} \mathrm{C}$ extended offshore in April 1999. On the southern California transect, negative anomalies $\left(\sim 1^{\circ} \mathrm{C}\right)$ were found nearshore (within $50 \mathrm{~km}$ ) in 1996, but the anomalies were positive offshore, while at $21^{\circ} \mathrm{S}$ and $37^{\circ} \mathrm{S}$ the anomaly was negative in the entire $500 \mathrm{~km}$ transect. The La Niña conditions off South America appeared to be more pronounced in 1996 than off southern California. At $33.5^{\circ} \mathrm{N}$, a positive anomaly of $1^{\circ}$ or greater extended offshore for more than $600 \mathrm{~km}$ between January 1997 and July 1998 , while at $21^{\circ} \mathrm{S}$ the anomaly persisted until September 1998. Negative anomalies commenced in October 1998 at $33.5^{\circ} \mathrm{N}$, and they surpassed $-1^{\circ} \mathrm{C}$ from February to May 1999 though they were decreasing by October 1999 . At $21^{\circ} \mathrm{S}$ the negative anomaly switch was almost immediate in September 1998 and persisted (though weak, less than $-1{ }^{\circ} \mathrm{C}$ ) until the end of 1999. La Niña conditions in 1999 appeared shorter-lived but more intense in the southern part of the California Current than off South America.

[56] Kahru and Mitchell [2000] used remote sensing observations to study the evolution of SST and chlorophyll concentrations between $20^{\circ} \mathrm{N}$ and $40^{\circ} \mathrm{N}$. They found that the area of eutrophic waters (concentrations exceeding $1 \mathrm{mg}$ $\mathrm{Chl} \mathrm{m}{ }^{-3}$ ) decreased in 1998 throughout the study area but that the area of mesotrophic waters (concentrations between 0.2 and $1 \mathrm{mg} \mathrm{Chl} \mathrm{m}^{-3}$ ) increased north of $\sim 36^{\circ} \mathrm{N}$ and off Baja California (south of $30^{\circ} \mathrm{N}$ ). The increased chlorophyll off Baja occurred in warm offshore waters and they propose that it is associated with a bloom of phytoplankton carrying out nitrogen fixation.

[57] P. M. DiGiacomo and M.-E. Carr (Interannual variability of chlorophyll in the California Current System: Effects of the 1997-1998 El Niño, in preparation) also using remote sensing observations to study the El Niño in the California Current system, found that chlorophyll concentrations were reduced between November 1997 and March 1998 as compared to the same month of the previous year. The reduction was greatest $(>50 \%)$ between $31^{\circ} \mathrm{N}$ and $38^{\circ} \mathrm{N}$ within a few hundred kilometers of the coast though 
increases were observed in offshore waters of the Pacific Northwest and of Baja California.

\section{Conclusions}

1. Throughout the study period the largest Ekman transport, $\Delta \mathrm{SST}$, and chlorophyll concentrations were found north of $15^{\circ} \mathrm{S}$, followed closely by the region between $35^{\circ} \mathrm{S}$ and $42^{\circ} \mathrm{S}$.

2. The impact of El Niño and interannual variability of the upwelling proxies decreased south of $25^{\circ} \mathrm{S}$.

3. La Niña conditions characterized the first part of the study period: SSH and SST anomalies were negative and alongshore transport residuals were primarily equatorward between January 1996 and March 1997. Ekman transport was offshore and SST was negative along the entire coast; chlorophyll concentrations surpassed $1 \mathrm{mg} \mathrm{Chl} \mathrm{m}^{-3}$ north of $18^{\circ} \mathrm{S}$ and between $32^{\circ} \mathrm{S}$ and $38^{\circ} \mathrm{S}$.

4. El Niño presented two maxima in SSH, SST, and poleward transport: in May-August 1997 and December 1997 to January 1998, separated by a relaxation period in which positive anomalies decreased between August and September-November 1997.

5. In the first El Niño maximum (May-August 1997), peak SSH and SST anomalies exceeded $15 \mathrm{~cm}$ and $2{ }^{\circ} \mathrm{C}$ as far south as $40^{\circ} \mathrm{S}$ and $30^{\circ} \mathrm{S}$. Poleward transport residuals were maximum north of $20^{\circ} \mathrm{S}$. $\triangle \mathrm{SST}$ was $1-2^{\circ} \mathrm{C}$ weaker than in 1996. The second El Niño peak in SSH (December 1997 to January 1998) surpassed $30 \mathrm{~cm}$ north of $12^{\circ} \mathrm{S}$. Though upwelling-favorable winds increased north of $15^{\circ} \mathrm{S}$, SST $\left(-3^{\circ} \mathrm{C}\right.$ to $\left.<2^{\circ} \mathrm{C}\right)$ and chlorophyll concentrations $\left(<0.47-1 \mathrm{mg} \mathrm{Chl} \mathrm{m}^{-3}\right)$ were the lowest of the entire record.

6. By September 1998, SSH and SST anomalies were negative $\left(<-5 \mathrm{~cm}\right.$ and $\left.-2{ }^{\circ} \mathrm{C}\right)$, though not as strongly negative as in 1996. Geostrophic transport residuals were predominantly equatorward. The wind pattern and $\triangle \mathrm{SST}$ were very similar to that of 1996 . Chlorophyll concentrations recovered rapidly after February 1998.

7. Under El Niño conditions the coastal band of high chlorophyll was reduced in offshore extent and nearshore concentrations suffered lesser impact than those in the offshore region. This was visualized by increasing the spatial scale used to average chlorophyll concentration. The evolution and impact of El Niño forcing was enhanced both in magnitude (larger) and onset (earlier) and duration (longer) in larger bins.

8. The offshore transects at select locations $\left(10^{\circ} \mathrm{S}, 21^{\circ} \mathrm{S}\right.$, and $37^{\circ} \mathrm{S}$ ) indicate that even when anomalous conditions extended offshore, they were always maximum near the coast. The offshore extent of upwelling was minimum at $21^{\circ} \mathrm{S}$ (usually $<100 \mathrm{~km}$ ) while it extended up to $300 \mathrm{~km}$ offshore at $10^{\circ} \mathrm{S}$ and $37^{\circ} \mathrm{S}$.

9. The averaged SSH and alongshore transport measured by the altimeter showed decreased impact of El Niño conditions to the south, although clear positive anomalies in SSH and a shift to poleward flow occurred at all three locations.

10. Present results indicate that the 1997-1998 was comparable in impact and duration to the 1982-1983 event though the timing differed. Higher resolution regional studies reached similar conclusions to those revealed by the monthly mean remotely sensed observations presented here.
11. El Niño conditions off North America were similar to those observed off South America although timing was slightly different due to the different latitude range, topography, and seasonal cycle. The La Niña conditions measured from space-borne sensors of 1998-1999 in the Peru-Chile Current were not as strong as during 1996 although they appear to have been significant in the California Current.

[58] Acknowledgments. We are grateful to two anonymous reviewers and Robert Anderson for valuable comments that improved the manuscript. We thank Tim Liu, Wendy Tang, and the NSCAT project for the gridded ERS-1 and NSCAT data, CERSAT for the ERS-2 monthly files, the Goddard DAAC and the SeaWiFS Science Project for the SeaWiFS data set, the National Oceanic and Atmospheric Administration (NOAA)/NASA AVHRR Pathfinder project for providing daily sea surface temperature via the JPL-PODAAC, and the University of Hawaii for tide gauge data. The authors thank the National Space Development Agency of Japan (NASDA), the SIMBIOS and SeaWiFS Projects (Code 970.2), and the Goddard Earth Sciences Distributed Active Archive Center (Code 902) at the NASA Goddard Space Flight Center (Greenbelt, MD 20771) for the production and distribution of these data, respectively. These activities are sponsored by NASA's Earth Science Enterprise Program and NASDA. Funding for ACT came from NASA grants NAG5-6558 and NAG5-6604 and National Science Foundation (NSF) grant OCE-9711919 (part of the U.S. GLOBEC NEP Program). Funding for MEC was provided by the NASA Ocean Biogeochemistry Program and for PTS by JPL grants 958128 (TOPEX) and 1206714 (Jason-1), NASA grants NAG5-4947 (EOS) and NAG5-6604, and NSF/NASA grant OCE-9711344 (U.S. GLOBEC NEP Program). This is contribution 351 of the U.S. GLOBEC program, jointly funded by the NSF and the NOAA. The research described in this paper was carried out in part at the Jet Propulsion Laboratory, California Institute of Technology, under a contract with NASA.

\section{References}

Bakun, A., Patterns in the Ocean: Ocean Processes and Marine Population Dynamics, Calif. Sea Grant Coll. Syst. in cooperation with Centro de Invest. Biol. del Noroeste, La Paz, BCS, Mexico, 1996.

Barber, R. T., The ocean basin ecosystem, in Concepts of Ecosystem Ecology, edited by J. Alberts and L. R. Pomeroy, pp. 166-188, SpringerVerlag, New York, 1988.

Barber, R. T., and R. L. Smith, Coastal upwelling ecosystems, in Analysis of Marine Ecosystems, edited by A. R. Longhurst, pp. 31-68, Academic, San Diego, Calif., 1981

Barnston, A., M. Glantz, and Y. X. He, Predictive skill of statistical and dynamical climate models in sst forecasts during the 1997-98 El Niño episode and the 1998 La Niña onset, Bull. Am. Meteorol. Soc., 802, $217-$ 243, 1999

Behrenfeld, M. J., et al., Biospheric primary production during an ENSO transition, Science, 291(5513), 2594-2597, 2001

Blanco, J. L., M.-E. Carr, A. Thomas, and P. T. Strub, Hydrographic conditions off of northern Chile during the 1996-1998 La Niña and El Niño, J. Geophys. Res., 107(C3), 3017, doi:10.1029/2001JC001002, 2002.

Bograd, S. J., and R. J. Lynn, Physical-biological coupling in the California Current, during the 1997-99 El Niño-La Niña cycle, Geophys. Res. Lett., 28, 275-278, 2001.

Bograd, S. J., P. M. DiGiacomo, T. L. Hayward, T. R. Baumgartner, K. D. Hyrenbach, R. J. Lynn, A. Mantyla, T. R. Baumgartner, B. Lavaniegos, and C. S. Moore, The state of the California Current, 1999-2000: Forward to a new regime?, Calif. Coop. Ocean. Fish. Invest. Rep., 41, 26$52,2000$.

Carr, M.-E., Estimation of potential productivity in eastern boundary currents using remote sensing, Deep Sea Res., Part II, 49, 59-80, 2002.

Chávez, F. P., A comparison of ship and satellite chlorophyll from California and Peru, J. Geophys. Res., 100, 24,845-24,862, 1995.

Gill, A. E., Atmosphere-Ocean Dynamics, Academic, San Diego, Calif., 1982.

Hayward, T. L., El Niño 1997-98 in the coastal waters of southern California: A timeline of events, Calif. Coop. Ocean. Fish. Invest. Rep., 40, 29-62, 1999.

Hayward, T. L., et al., The state of the California Current in 1998-1999: Transition to cool-water conditions, Calif. Coop. Ocean. Fish. Invest. Rep., 40, 29-62, 1999 .

Hill, A. E., B. M. Hickey, F. A. Shillington, P. T. Strub, K. H. Brink, E. D. Barton, and A. Thomas, Eastern ocean boundaries, in The Sea, vol. 11, 
part B, edited by A. R. Robinson and K. H. Brink, pp. 29-68, John Wiley, New York, 1998.

Kahru, M., and B. G. Mitchell, Influence of the 1997-1998 El Niño on the surface chlorophyll in the California Current, Geophys. Res. Lett., 2718, 2937-2940, 2000.

Miller, A. J., E. Di Lorenzo, D. J. Nielson, B. D. Cornuelle, and J. R. Moisan, Modeling CalCOFI observations during El Niño: Fitting physics and biology, Calif. Coop. Ocean. Fish. Invest. Rep., 41, 87-97, 2000.

Morales, C. E., M. Braun, H. Reyes, J. L. Blanco, and A. Davies, Anchovy larval distribution in the coastal zone off northern Chile: The effect of dissolved oxygen concentrations and of a cold-warm sequence 1990-95, Invest. Mar. Valparaíso, 24, 77-96, 1996.

Murtugudde, R. G., S. R. Signorini, J. R. Christian, A. J. Busalacchi, C. R. McClain, and J. Picaut, Ocean color variability of the tropical Indo-Pacific basin observed by SeaWiFS during 1997-1998, J. Geophys. Res., 104, 18,351-18,366, 1999.

Nykjaer, L., and L. Van Camp, Seasonal and interannual variability of coastal upwelling along northwest Africa and Portugal from 1981 to 1991, J. Geophys. Res., 99, 14,197-14,207, 1994.

Parrish, R. H., A. Bakun, D. M. Husby, and C. S. Nelson, Comparative climatology of selected environmental processes in relation to eastern boundary current pelagic fish reproduction, in Proceedings of the Expert Consultation to Examine Change in Abundance and Species of Neritic Fish Resources, San Jose, Costa Rica, vol. 2913, edited by G. D. Sharp and J. Csirke, pp. 731-778, FAO Fish Rep., 1983.

Pauly, D., and V. Christensen, Primary production required to sustain global fisheries, Nature, 374, 255-257, 1995.

Philander, G., El Niño and La Niña, Am. Sci., 77, 451-459, 1989.

Reynolds, R. W., and T. Smith, Improved sea surface temperature analysis using optimum interpolation, J. Clim., 7, 929-948, 1994.

Sánchez, G., R. Calienes, and S. S. Zuta, The 1997-98 El Niño and its effects on the coastal marine ecosystem off Peru, Calif. Coop. Ocean. Fish. Invest. Rep., 41, 98-116, 2000.

Shaffer, G., S. Hormazabal, O. Pizarro, and S. Salinas, Seasonal and interannual variability of currents and temperature off central Chilean coast, J. Geophys. Res., 104, 29,951-29,961, 1999.

Strub, P. T., and C. James, The 1997-1998 oceanic El Niño signal along the southeast and northeast Pacific boundaries: An altimetric view, Prog. Oceanogr., 54(1-4), 439-458, 2002a.

Strub, P. T., and C. James, Altimeter-derived surface circulation in the large-scale NE Pacific gyres, part 2, 1997-1998 El Niño anomalies, Prog. Oceanogr., 53(2-4), 163-183, 2002b.
Strub, P. T., J. M. Mesias, V. Montecino, J. Rutllant, and S. Salinas, Coastal ocean circulation off western South America, in The Sea, vol. 11, edited by A. R. Robinson and K. H. Brink, pp. 273-313, John Wiley, New York, 1998.

Thomas, A. C., Seasonal distributions of satellite-measured phytoplankton pigment concentration along the Chilean coast, J. Geophys. Res., 104, $25,877-25,890,1999$

Thomas, A. C., F. Huang, P. T. Strub, and C. James, Comparison of seasonal and interannual variability of phytoplankton pigment concentrations in the Peru and California Current systems, J. Geophys. Res., 99, $7355-7370,1994$

Thomas, A. C., J. L. Blanco, M.-E. Carr, P. T. Strub, and J. Osses, Variability of satellite-measured chlorophyll and temperature off northern Chile during the 1996-1998 La Niña and El Niño, J. Geophys. Res., 106, 899-915, 2001a.

Thomas, A. C., M.-E. Carr, and P. T. Strub, Chlorophyll variability in eastern boundary currents, Geophys. Res. Lett., 2818, 3421-3424, $2001 \mathrm{~b}$.

Ulloa, O., R. Escribano, S. Hormazabal, R. A. Quiñones, R. R. González, and M. Ramos, Evolution and biological effects of the 1997-98 El Niño in the upwelling ecosystem off northern Chile, Geophys. Res. Lett., 288, $1591-1594,2001$.

Wooster, W. S., A. Bakun, and D. R. McLain, The seasonal upwelling cycle along the eastern boundary of the north Atlantic, J. Mar. Res., 34, $131-$ 141,1976

Yáñez, E., A. González, and M. A. Barbieri, Estructura térmica superficial del mar asociada a la distribución espacio-temporalde sardina y anchoveta en la zona norte de Chile entre 1987-1992, Invest. Mar. Valparaíso, $23,123-147,1995$.

J. L. Blanco, Center for Coastal Physical Oceanography, Old Dominion University, Norfolk, VA, USA.

M.-E. Carr, Jet Propulsion Laboratory MS 300-323, California Institute of Technology, 4800 Oak Grove Drive, Pasadena, CA 91009, USA. (mec@ pacific.jpl.nasa.gov)

P. T. Strub, College of Oceanic and Atmospheric Sciences, Oregon State University, Corvallis, OR, USA.

A. C. Thomas, School of Marine Sciences, University of Maine, Orono, ME, USA. 